Fiscal Stimulus in a Monetary Union: Evidence from Eurozone Regions 
The Working Paper series of the Oesterreichische Nationalbank is designed to disseminate and to provide a platform for discussion of either work of the staff of the OeNB economists or outside contributors on topics which are of special interest to the OeNB. To ensure the high quality of their content, the contributions are subjected to an international refereeing process. The opinions are strictly those of the authors and do in no way commit the OeNB.

The Working Papers are also available on our website (http://www.oenb.at) and they are indexed in RePEc (http://repec.org/).

Publisher and editor

\section{Editorial Board of the Working Papers}

Coordinating editor

Design

\author{
Oesterreichische Nationalbank \\ Otto-Wagner-Platz 3, 1090 Vienna, Austria \\ PO Box 61, 1011 Vienna, Austria \\ www.oenb.at \\ oenb.info@oenb.at \\ Phone (+43-1) 40420-6666 \\ Fax (+43-1) 40420-046698
}

Doris Ritzberger-Grünwald, Ernest Gnan, Martin Summer

Martin Summer

Communications and Publications Division

\section{DVR 0031577}

ISSN 2310-5321 (Print)

ISSN 2310-533X (Online)

(c) Oesterreichische Nationalbank, 2016. All rights reserved. 


\section{Editorial}

On the occasion of the 65th birthday of Governor Klaus Liebscher and in recognition of his commitment to Austria's participation in European monetary union and to the cause of European integration, the Oesterreichische Nationalbank (OeNB) established a “Klaus Liebscher Award”. It has been offered annually since 2005 for up to two excellent scientific papers on European monetary union and European integration issues. The authors must be less than 35 years old and be citizens from EU member or EU candidate countries. Each "Klaus Liebscher Award" is worth EUR 10,000. The two winning papers of the twelfth Award 2016 were written by Maria Coelho and by François de Soyres. The first paper is presented in this Working Paper while François de Soyres’ contribution is contained in Working Paper 209.

November 25, 2016 


\title{
Fiscal Stimulus in a Monetary Union: Evidence from Eurozone Regions
}

\author{
Maria Coelho*
}

\begin{abstract}
This paper contributes to the open economy local fiscal multiplier literature by estimating regional output and employment responses to federal expenditure shocks in the European Union. In particular, similarly to the literature on foreign aid and growth, I use shocks to the supply of federal transfers (European Commission commitments) of structural fund spending by subnational region as instruments for annual realized expenditure in a panel from 2000-2013. I find a large, contemporaneous multiplier of 1.7 which translates into a cumulative multiplier of 4 three years after the shock. Furthermore, using a novel dataset on bilateral trade between EU regions, I find evidence of demand-driven spillovers up to three years after a shock.
\end{abstract}

*Ph.D. candidate, Department of Economics, University of California at Berkeley. Contact: mcoelho@econ.berkeley.edu. I am especially grateful to my dissertation committee chair Alan Auerbach for his guidance, encouragement and invaluable feedback on this project. I am also grateful to Barry Eichengreen, Yuriy Gorodnichenko, and Emmanuel Saez for their feedback and helpful advice at different stages of this paper. This project also benefited from discussions with Sasha Becker, Carola Binder, Erik Johnson, John Mondragon, Christina and David Romer, Johannes Wieland, and seminar participants at Berkeley. I am extremely grateful to John Walsh and Mark Thissen for kindly sharing the underlying data, without which this project would not have been possible. I acknowledge financial support from Fundação para a Ciência e Tecnologia and the Robert D. Burch Center for Tax Policy and Public Finance. All remaining errors are my own. 


\section{Introduction}

Divergent estimates of government spending multipliers (Giavazzi and Pagano (1990); Ramey (2011); Blanchard and Perotti (2002); Fatas and Mihov (2001); Hall (2009)), have historically resulted in large part from i) the difficulty in finding precisely measured exogenous changes in government spending, and ii) disentangling the contemporaneous effects of confounding variables such as tax increases or tighter monetary policy. Recent contributions to this literature have tried to circumvent some of these traditional obstacles by focusing either on estimating state-dependent multipliers (Auerbach and Gorodnichenko (2012, 2013)), or on government spending at lower levels of aggregation, using shocks to subnational spending in the US (Chodorow-Reich et al. (2012); Nakamura and Steinsson (2014)) and Japan (Bruckner and Tuladhar (2011)). This paper fits in the latter line of literature by extending the estimation of the open economy relative multiplier à la Nakamura and Steinsson (2014) to the European Union ${ }^{1}$. I do so in particular by using shocks to the supply of federal transfers to EU subnational regions as instruments of exogenous changes in local government spending.

There is also a growing parallel literature that has attempted to measure the effect of European structural and cohesion funds on regional growth and employment (Mohl and Hagen (2011, 2010); Becker et al. (2010, 2012, 2013)) and more broadly to assess the welfare gains from a redistributive fiscal union in Europe (Bargain et al. (2013); Economides et al. (2016)). Sala-i-Martin (1996) initiated the debate by finding no evidence of improved growth or convergence in EU regions by looking at the combined Structural Funds Programme. However, thereafter most empirical findings have lent support to an average positive impact of spending on per capita GDP growth (Beugelsdijk and Eijffinger (2005); Ederveen et al. (2006); Becker et al. (2010); Mohl and Hagen (2011)), alongside inconclusive employment effects. More-

\footnotetext{
${ }^{1} \mathrm{~A}$ priori, one could expect these multipliers to be different in the US and Europe due to nontrivial differences in institutional constraints and characteristics of financial services, goods markets and labor mobility, for example.
} 
over, the effects are often heterogeneous across funding categories and regions (Mohl and Hagen (2011); Becker et al. (2012, 2013); Mohl and Hagen (2010)), as are the magnitudes and even signs of the corresponding multipliers. Nonetheless, this literature has remained largely at the margin of the existing fiscal multiplier literature in the US. This paper bridges the two sets of research, by explicitly considering fiscal multipliers across different states in the context of regional structural transfers in Europe. Furthermore, this paper distinguishes itself methodologically from the latter strand of papers by using an instrumental variable approach to identify exogenous (government) supply-driven shocks to federal transfers. Becker et al. (2010) explore a regression discontinuity design within a binary treatment framework to estimate the impact of receiving structural funds aggregated by programming period for 1994-99 and 2000-06 at the NUTS $3^{2}$ level (more disaggregated than the level used in this paper), while Becker et al. (2013) estimate dose-response functions (to treatment intensity) through generalized propensity scores using the same underlying data. Notably, the latter paper is able to estimate heterogeneous treatment effects across regions (rather than just a local average treatment effect at the threshold). For comparison, I also replicate the regression discontinuity strategy in Becker et al. (2010) using my preferred instrumented treatment variable in section C. However, both strategies miss time-variant information, which is captured in Mohl and Hagen (2011), as well as in the panel IV estimates which constitute the core contribution of this paper. Finally, to the best of my knowledge, no other paper has yet used data from the recent financial and sovereign crisis period 2007-13 - a period for which understanding the response of regional macroeconomic outcomes to fiscal stimulus is particularly valuable, but also bound to exhibit exceptional characteristics.I find an average 1.72 contemporaneous open economy relative multiplier on output growth ${ }^{3}$

\footnotetext{
${ }^{2}$ NUTS stands for Nomenclature des Unités Territoriales Statistiques used by Eurostat. At their most aggregated level (NUTS 1) they roughly correspond to Germany's Bundesländer with an approximate minimum of 3 million people; NUTS 2 range between 800,000 and 3 million people, with NUTS 3 comprising the smallest of the aggregates, equivalent to French Départements. Currently there are a total of 97 regions at NUTS 1, 271 regions at NUTS 2 and 1303 regions at NUTS 3 level.

${ }^{3}$ After adjusting the estimated coefficients of interest for co-financing of $40 \%$ on average by
} 
for the poorest regions ${ }^{4}$, larger than those previously identified in the literature. Three years after the shock, I find a cumulative muliplier of 4.04. In addition, this large effect is fully explained by increased compensation of currently employed workers. In line with the findings of Auerbach and Gorodnichenko (2012), my estimates suggest output multipliers were larger post-2006. Finally, with the exception of two and three-year horizons post-2006, I find no significant effects on unemployment.

The results of this paper are particularly pertinant from a policy perspective to understand the potential impact of large public investment programs aimed at stimulating specific incipient economic sectors (such as renewable energy), the restructuring of exisiting economic activity with the collaboration of private investors to improve regional productivity (such as small and medium enterprise support and R\&D), or infrastructure development. In the first half of 2015, the European Commission and the European Investment Bank have established a European Fund for Strategic Investments (EFSI), an initial $€ 21$ billion fund over a three-year period intended to garner $€ 315$ billion in additional private capital by addressing perceived existing market failures that hamper private investment in Europe (European Commission (2015)). If successful in this premise, the overall size of the program would be larger per annum than the American Recovery and Reinvestment Act of 2009. The rationale underpining this type of program is that by passing some of the project risk onto public institutions (effectively partially insuring idiosyncratic risky returns), public capital injections can attract private investors to projects that would otherwise not have access to credit. However, the extraordinarily high private-public leverage ratio of 15 to 1 has drawn ongoing skepticism. Since the focus areas for the EFSI overlap closely with those of the European Structural Funds Programme explored in this paper, the results presented here have direct applications for the evaluation and implementation of similar large-scale public investment and stimulus programs.

private entities and local/national governments.

\footnotetext{
${ }^{4}$ Those under Objective 1 of the Cohesion Policy.
} 
Finally, in section 5 I find that due to the small open economy nature of these regions within a fixed exchange rate regime, a significant portion of the estimated multipliers are in fact due to fiscal shocks elsewhere. This result is consistent with the findings of Auerbach and Gorodnichenko (2013) at the cross-country level, as well as with several recent studies observing that coordinated contractionary fiscal policy across closely integrated countries (such as within the Eurozone) could in fact be selfdefeating even in models in which a unilateral contraction was expansionary, due to offsetting current account spillovers between regions (Holland and Portes (2012)).

\section{Background and Data: European Regional Con- vergence Funds}

In order to promote economic and social cohesion in the European Union, more than $35 \%$ of the Union's budget is transferred to the less-favored regions. These include regions lagging behind in development, undergoing restructuring or facing specific geographical, economic or social problems. There are three mutually exclusive schemes under this programme: Objective 1 or Convergence Objective, aimed at the development and structural adjustment of the poorest regions in Europe; Objective 2 (now Regional Competitiveness and Employment objective) is intended to assist in the socio-economic convergence of declining industrial regions and rural areas; and Objective 3 (now European Territorial Cooperation objective) supports the modernization of education, training and employment policies in regions not covered by Objective 1. (European Commission (2010)) In this paper, I focus exclusively on regions covered under Objective 1 and 2 transfers. Combined, they account for the lion's share ${ }^{5}$ of expenditures under the Structural Funds Programme. NUTS 2 level regions are eligible to receive Objective 1 /Convergence funds if their average GDP per capita in purchasing power parity terms (PPP) in the preceding years falls at or below $75 \%$ of the EU-wide average. The funds involved in these programs are sub-

\footnotetext{
${ }^{5}$ Close to $88 \%$ in the $2000-06$ programming period, and $97 \%$ in the $2007-13$ period.
} 
stantial. The budget for the EU Cohesion Policy is roughly one third of the total EU budget, $€ 347.41$ bn for the planning period 2007-2013. In the same period, the Convergence objective alone amasses a total of $€ 264 \mathrm{bn}$. Furthermore, by the principle of additionality $^{6}$, EU assistance is required to be additional to national funding and not to replace it - member states must maintain their own public expenditure at least at the level it was at in the preceding period. Hence, a priori, the effect of these funds should be felt directly through program expenditures rather than through availability of additional fiscal reserves for the national states. In terms of policy areas, most of the operational programs utilizing these funds consist of public investment in infrastructure and purchases of goods and services/subsidies/credit to private enterprises in fields such as environment and competitiveness (R\&D, communication).

In practice, the physical movement of funds from the Union to the member states is done through reimbursement of certified expenditures to the final beneficiaries (which can be either public or private bodies). Most ERDF/CF assistance is granted in the form of non-repayable grants or "direct aid", and to a lesser degree refundable aid, interest-rate subsidies, guarantees, equity participation, and participation in venture capital. The timeline of transfers involves first a commitment of a given amount of funds to a NUTS 2 region during a programming period; this constitutes an upper bound on the actual amount eventually received by regions, and unofficial guidance figures for commitments are also used by the European Commission (EC) in addition to the binding total programming period commitments. Total commitment allocation by member state gets decided mainly on the basis of actual need for convergence funds several years prior to implementation (i.e., lower income states get proportionally higher funds), but also on the basis of negotiations between member states at the European Council and European Commission preceding each 6-7 year program (Heijman and Koch (2011)). Hence, I can reasonably treat them as being exogenous to contemporaneous changes in regional economic variables. After these commitments are announced, local public authorities and private agents

\footnotetext{
${ }^{6}$ Whether this principle is actually binding is debatable. There is plausible reason to believe in fact some of these transfers are substituting, rather than adding to, local public spending.
} 
(firms or individuals) can submit project proposals to benefit from a share of these commitments. These proposals are reviewed and accepted/rejected by the European Commission, upon which project selections are made - these are project specific ceilings on fund transfers. Finally, up to the allowed project selection amount, project managers (individuals, firms or local public authorities who proposed them) will typically be reimbursed for realized expenditures after they are incurred. The last two steps in the transfer process are thus driven by aggregate demand conditions, and thus likely respond endogenously to regional business cycle conditions. Orthogonally to business cycle fluctuations, a surprisingly large percentage of committed funds are left on the table every programming period (as much as $50 \%$ in some regions) - a reflection of low absorptive capacity (Becker et al. (2012)) -, which also weakens the link between original commitment allocations and final expenditures reimbursed.

In addition, the funds allocated to each project almost always require some degree of co-financing by either national/local authorities or private agents. For example, the expansion of the port of Augusta (Italy) channelled a $€ 119.5 \mathrm{~m}$ total investment, out of which $29.9 \%$ was financed by the European Regional Development Fund; in turn, the conversion of an industrial site in Caceres (Spain) into a green community space and small enterprise workspace represented a $€ 5.5 \mathrm{~m}$ investment, out of which $75 \%$ was financed by the EU. Thus, access to non-EU forms of funding is a necessary condition for the implementation of these projects and associated transfers. This factor may influence the magnitude of the fiscal multiplier - directly, in that the federal expenditure "shock" used in the multiplier estimation must be adjusted upwards to reflect the true extent of any project-related expenditures, but also indirectly, in that regions undergoing a contraction in financial intermediation services may have asymmetric difficulty in successfully applying for or completing projects, and their influence in regional business cycle dynamics may be curtailed due to a financial accelerator effect (Bernanke et al. (1999)).

I use data on total amount of funds committed to and spent in NUTS 2 regions for each year of programming periods $2000-06$ and $2007-13^{7}$. The data was generously

\footnotetext{
${ }^{7}$ There are printed sources for annual regional commitments and expenditures 1994-99, which
} 
provided by the Directorate General for Regional Policy of the European Commission. Importantly, while data on commitments by region was available on an annual basis over 2000-2013, data on expenditures at a NUTS 2 level was only available by programming period total. Therefore, I imputed annual expenditure amounts by NUTS 2 by assuming that the year-on-year evolution of regional expenditure follows the same pattern (in percentage terms) as the evolution at the national level. In other words, within a 6 year programming period (PP), if $20 \%$ of the total corresponding expenditure at the national level occurred in year 1 of the PP, then I input $20 \%$ of the total PP expenditure in a given region in that country to year 1 , and so forth for every region and year. In addition, since expenditures relating to projects selected during the 2000-06 PP carry on well into the 2007-13 period, during the latter years I use not only actual annual EC commitments for the respective year in the 2007-13 PP as instruments, but also a counterfactual "remaining commitment" from 200006, which I construct by subtracting the sum of all realized expenditures until 2006 from the overall PP commitment, and geometrically reducing the net amount until 2013. Years from 2007 onwards thus use a "combined" two-part instrument, although I treat it as a single instrument in all estimates below. Hence, the key sources of variation in expenditure I am using in this paper are both the cross-section of NUTS 2 regions within each programming period, and annual changes across countries. In contrast, my core instrument (commitment) varies both at the cross-sectional and time series levels. Though there exist data on total expenditures for the 2000-06 programming period by NUTS 3 region $^{8}$, the lack of any comparable data for 2007-13 prevents us from using this level of disaggregation (which would have quadrupled the sample size). Furthermore, since commitments are determined at the NUTS 2 and not NUTS 3 level, my first stage IV strategy is naturally constrained to variation across NUTS 2 regions and over time. Data on GDP components, population, unemployment rates and business structural indicators is taken entirely from Eurostat. Figure 1 depicts the geographic incidence of these funds over two years in the sample,

can be used to expand the current database going back 5 years. TBC

${ }^{8}$ Sweco ex-post consulting report to the European Commission 
and Table ??tabsummary summarizes mean descriptive statistics by country. It is immediately apparent that structural funds are highly concentrated in "periphery" regions of the European Union, but even within these there is considerable variation in their proportion to local GDP over time. Note despite many regions receiving a relatively small share of funds, all regions receive a strictly positive amount from either Objective 1 or 2.

\section{$3 \quad$ Fiscal shock identification strategy}

As described in the previous section, due to the demand-driven nature of EU structural funds, annual fund expenditure across regions (or annual changes in this variable) is not an exogenous measure of a shock to regional fiscal policy. However, it is still our key variable of interest, in the sense that (excluding anticipatory effects) in theory shocks to federal transfers should affect regional outcomes once they are actually realized. In this paper, I propose using the original EC fund commitments as instruments for the actual expenditure realized. The former are highly predictive of ultimate expenditures, but are exogenously determined with respect to contemporaneous business cycle conditions, satisfying one of the critical identification assumptions for the estimation of fiscal multipliers mentioned in the introduction. This instrumentation is the most significant methodological difference between this paper and the most recent contributions to the structural funds impact evaluation literature (Mohl and Hagen (2011); Becker et al. (2010)). Using actual payments to regions as the explanatory variable without correcting (as suggested by this paper) for endogeneity with respect to regional business cycle conditions can lead to ambiguous biases in multiplier estimates. On the one hand, it could lead to an upward bias in the spending multiplier if an expansion in GDP is positively correlated with a rise in aggregate demand that boosts applications for EU co-funded projects. On the other hand, it could also lead to downward bias if there is substitutability between private/local public financing sources and European funds, such that more financing-constrained firms in recessions would need European funds more than during expansionary periods, and as such absorb a greater share of available commitments on the table. Finally, instrumenting for expenditures using commitments also 
allows us to attenuate some of the measurement error present in the construction of our annual expenditure series, given the data on commitments by year and region is more accurately collected than ultimate expenditures (whose reporting and verification is typically under the responsibility of different national and local authorities, often with little accountability towards the European Commission).

Furthermore, although I do not deal exclusively with regions within the Eurozone, I argue that I am able to maintain monetary policy and nominal interest rates constant, since the vast majority of other EU members in my sample have domestic currencies closely pegged to the Euro throughout the estimation period ${ }^{9}$, and $\operatorname{most}$ are scheduled to join the currency union in the near future (so I can expect their monetary policy to be aligned with the ECB's). As shown in several tables below, restricting our attention to Eurozone-only countries does not alter any of the results presented here. Moreover, while tax policy is not common across all regions, this variable should not be confounding in the traditional sense since EU funds are agreed ex-ante for 6-7 year plans, and the corresponding revenues needed to support them are pre-arranged during supranational negotiations years before the actual spending comes into effect at the regional level. Furthermore, member state contributions to the EU budget serve several other budgetary allocations beyond regional convergence (including agricultural subsidies, administrative expenses, etc), so their original incidence should also not be directly associated with ERDF disbursements.

Similarly to Nakamura and Steinsson (2014), I use $\frac{G_{t}-G_{t-1}}{Y_{t-1}}$ as my main explanatory variable capturing the fiscal shock ${ }^{10}$. This facilitates the direct interpretation of both the panel estimation coefficient and the regression discontinuity local average treatment effect as multipliers.

\section{Panel Instrumental Variables Estimation}

In the core section of this paper, I replicate Nakamura and Steinsson (2014) in a two-step instrumental variable dynamic panel estimation setup, where as previously

\footnotetext{
${ }^{9}$ With the exception of the United Kingdom.

${ }^{10}$ Note that Nakamura and Steinsson (2014) use a two-year cumulative shock, rather than annual.
} 
mentioned, I use changes in annual commitments to EU regions as instruments for changes in annual expenditures in those regions associated with EU structural funds transfers:

$$
\frac{Y_{i, t+h}-Y_{i, t-1}}{Y_{i, t-1}}=\alpha_{j, h}+\gamma_{t, h}+\beta_{h} \frac{G_{i, t}-\widehat{G}_{i, t-1}}{Y_{i, t-1}}+\delta_{h} X_{i}+\rho_{h} \frac{Y_{i, t-1}-Y_{i, t-2}}{Y_{i, t-2}}+\epsilon_{i, h}
$$

where $Y_{i, t+h}$ is the outcome variable (i.e., real GDP per capita growth, change in the unemployment rate) at horizon $h=0,1,2,3$ and changes in expenditures $G_{i, t}-\widehat{G}_{i, t-1}$ are instrumented using commitments $\left\{C_{i, t}, C_{i, t-1}\right\}$ according to the following first stage

$$
\Delta G_{i, t} \equiv G_{i, t}-G_{i, t-1}=\lambda_{j}+v_{t}+\theta_{i, t} C_{i, t}+\theta_{i, t-1} C_{i, t-1}+\mu X_{i}+\zeta_{i}
$$

Instrumenting for changes in expenditures using contemporaneous and lagged levels (rather than the change) of commitments enables more flexible weighting on each component of the change ${ }^{11}$, and is supported by stronger first stage relevance. I define the key government spending shock variable as $\Delta G_{i, t}$ in the baseline specification for comparability with the fiscal multiplier literature using domestic US data (Hall (2009); Serrato and Wingender (forthcoming); Chodorow-Reich et al. (2012); Nakamura and Steinsson (2014)), which commonly defines spending shocks as first (or second) differences due to the persistence of government spending levels. In contrast, existing literature studying the impact of European structural funds using dynamic panel data models typically uses levels of funds (either lagged or contemporaneous) as the key explanatory variable of interest (Ederveen et al. (2006); Mohl and Hagen $(2010,2011)$ ). This choice is also common in the literature examining the effects of foreign aid on developing countries (Clemens et al. (2004)). In order to bridge these two strands of literature, in Table 10 I run the same set of core regressions using $\frac{G_{i, t}}{Y_{i, t-1}}$ as the key explanatory variable of interest. However, since

\footnotetext{
${ }^{11}$ Instrumenting for $\Delta G_{i, t}$ using net $C_{i, t}-C_{i, t-1}$ implicitly imposes an equal weight on $C_{i, t}$ and $C_{i, t-1}$.
} 
$G_{i, t}$ has high serial correlation within each region, I add lags $\sum_{s=1}^{L} G_{i, t-s}$, where $L$ corresponds to the measured order of autocorrelation, in order to capture otherwise omitted variable effects of previous lags in spending on current output growth.

Due to my imputation of annual changes in expenditures from the national to the regional level, I cannot use region-specific fixed effects ${ }^{12}$. To compensate for this, I use both country fixed effects $\left(\alpha_{j}, \lambda_{j}\right)$, and values of region-specific control variables $X_{i}$ (average years of education, share of employment in manufacturing/industry, and share of employment in the public sector) at the beginning of the sample period ${ }^{13}$. I also include year fixed effects $\left(\gamma_{t}, \nu_{t}\right)$. Maximizing likelihood of fit according to BIC, I include only one lag of the outcome variable on the right-hand side. Regional GDP components and federal transfers are deflated using annual national inflation. Standard errors are clustered at the regional level ${ }^{14}$. I also exclude a few outlier GDP growth region-year observations ${ }^{15}$. Figure 2 illustrates the relationship between key first stage variables for Objective 1 regions in a representative year. There is a strong linear positive correlation between committed and ultimately contemporaneously spent funds, with the lack of full absorption of commitment ceilings evident from the fact that most observations sit below the 45 degree line. Exceptions at the lower end of the spectrum where expenditures in a given year surpass the Commission's annual commitment (such as GR3, the NUTS 2 region corresponding to Athens) are usually the consequence of carry-over commitments from previous years (i.e., projects formerly approved with expenditures incurred with a lag).

\footnotetext{
${ }^{12}$ Doing so would eliminate most of the cross-sectional variation between NUTS 2 regions, since these only vary by programming period and not by year, except insofar as their home state pattern also changes.

${ }^{13}$ Their values in 2000 .

${ }^{14}$ Unfortunately, given the short span of our time series, I cannot use Driscoll-Kraay HAC standard errors; for consistency, these need $T>20-25$.

${ }^{15}$ In particular, I exclude EE 2009/2011, LT 2009/2010, as well as SE33 2010 (abnormally sharp growth/recession and very low transfers change), and ES61 2010 (abnormally large increase in transfers); UKF1 (2009/2010/2011), and NL11 2008.
} 


\subsection{Analysis of results}

In the core specifications, I find large positive statistically significant output multipliers. In addition, results seem to be persistent over time ${ }^{16}$. Within Objective 1 regions, estimates are of larger magnitude and significance post-2006 (Table 2). Across the board, Objective 1 regions exhibit a large multiplier, slightly more so outside of the EU-12 ${ }^{17}$ (see Table 4). In theory, regions outside of the EU-12 could be at a developmental disadvantage compared to older member states, ridden with institutional characteristics that would jeopardize their efficient absorption of the federal funds into the local economy, as some studies have suggested fiscal multipliers to be substantially smaller in developing countries than in industrialized ones (Ilzetzki et al. (2013)); notwithstanding, my results do not seem to corroborate such a hypothesis. Overall, the estimated open economy relative multipliers are larger than most of those found by the literature, as well as more immediate (Mohl and Hagen (2010) only find effects with a 4-year lag, for instance). Part of the explanation for the magnitude of the multipliers found has to do with the fact that due to co-funding in the order of $40 \%$ by local authorities or private agents, I am effectively underestimating the explanatory fiscal shock (and thus inflating the true multiplier). Adjusting for this matching requirement, the contemporaneous expenditure multiplier is 1.7 in the main specification for Objective 1 regions, and cummulatively 4 over the course of three years. Moreover, as an open economy relative multiplier, it encompasses spillover effects from shocks to nearby regions, as well as regions economically closely linked. I deal with the estimation of spillovers in more detail in section 5 .

In addition, in line with both Mohl and Hagen (2011) and Becker et al. (2010), I do not observe a statistically significant effect on unemployment in most specifications. A noteworthy exception to this are large and significant negative multipliers on unemployment in Objective 1 regions post-2006. A combination of liberalizing labor

\footnotetext{
${ }^{16}$ Rather than hump-shaped as in Blanchard and Perotti (2002).

${ }^{17}$ The original Eurozone member states.
} 
market reforms in countries affected by sovereign rescue plans (making it cheaper to both fire and hire workers temporarily) and the slackness of the labor market post-2010 may have contributed to this effect. One possible explanation for the large but isolated negative contemporaneous unemployment effect for Objective 2 regions (Table 6) could be that short-duration retraining programmes (more commonly encompassed under Objective 2) temporarily reduce reported unemployment. Florio and Moretti (2014) also suggest there may be significant heterogeneity across industries underlying aggregate estimates such as the ones presented in this paper.

Moreover, I find non-significant effects of transfers on output growth for objective 2 regions (Table 3). Mohl and Hagen (2010) find negative effects for Objective 2 funds on GDP (looking exclusively at EU-15). Out of the reasons proposed by the authors for those findings, the one most consistent with my findings is the existence of some crowding out of local public investment. In particular, I cannot reject the hypothesis that structural funds are being used to indirectly reduce public deficits, nor of crowding out of private investment itself. Furthermore, diversion of private investment and government spending to cross-border projects where growth stimulus is going to be counted in neighboring regions may be more pronounced if Objective 2 regions are more open to trade than Objective 1 regions, causing them to ceteris paribus lose in spillovers (Ilzetzki et al. (2013)), since conditional on fixed exchange rates, in theory greater trade openness leads to smaller measured multipliers (Nakamura and Steinsson (2014)); this is plausible since most of the negatively affected regions are relatively more central geographically.

Furthermore, across almost all specifications with output growth, investment and wages as the dependent variable, I find evidence of mean-reversion. This is however not the case for regressions with unemployment change as the dependent variable which attests to the presence of hysteresis. Negative autoregressive coefficients, especially at short lags, are consistent both with greater measurement error in regional economic series, and with frequent asymmetric shocks and higher specialization at the regional level, corroborated by the literature on regional business cycles in Europe (De Grauwe and Vanhaverbeke (1991)). Furthermore, it is also consistent with the downward bias of fixed effect estimation of a dynamic panel model (Nickell (1981)). 
Excluding this lagged outcome variable from our estimations does not affect the key multiplier results.

Finally, I run a series of robustness tests of the results from the baseline specification. The first column of Table 2 regresses $\frac{Y_{i, t+1}-Y_{i, t-2}}{Y_{i, t-2}}$ on $\frac{G_{i, t}-\widehat{G}_{i, t-1}}{Y_{i, t-1}}$ (in words, the first-lag of the dependent variable on the federal expenditure shock at time $t$ ), in order to capture any measurable anticipation effects. Given the significant degree of autocorrelation of the outcome variable series, it is theoretically possible that anticipatory effects could partially explain the high multipliers I find in the baseline results, thereby reducing their contemporaneous magnitude. This possibility is consistent with the persistent and potentially predictable magnitude of these transfer programs in practice, which could induce private firms, households, and local governments to expand their investment and consumption patters in anticipation of future funds, thereby increasing contemporaneous and future growth rates. However, as shown in column 1 of Table 2, I find no evidence that is the case. Econometrically, this result also mitigates the concern that my definition of a right-hand side variable "shock" as the year-on-year change in expenditures to GDP might not be a true "shock" in the sense of being exogenous and not anticipated by economic agents. In addition, Tables 10, 11, and 12 provide estimates over the core sample and specifiication using alternative measures of either the regressor of interest, the dependent variable, or standard errors. Table 10 replicates the baseline estimation for Objective 1 regions using actual expenditure levels instead of changes as the key shock of interest. There are non-trivial differences in the results. In particular, while the multiplier for the entire sample period is in fact positive and even larger than that found using changes as a measure of fiscal shock, it is not statistically significant in post-2006 years. A possible explanation for this discrepancy could be the relatively poor macroeconomic performance of regions in sovereign-debt crisis ridden countries post-2008, which were also highly dependent on European Cohesion Funds on a level basis (thus a sample selection artifact). It is also difficult to disentangle what the counterfactual decline in output growth and employment would have been absent these expenditures, so the absence of a significant effect under this specification should not be taken as conclusive evidence of the lack of a positive stimulus 
effect. Furhermore, as mentioned earlier in the paper, the sharp contraction of financial intermediation services during the sovereign-debt crisis in Southern Europe and Ireland could have also hampered an important transmission channel of the multiplier. Table 11 uses the same definition of the shock variable on the right-hand side as the baseline specification (year-on-year changes), but replaces year-on-year actual GDP growth on the left-hand side with the output gap, defined as $\frac{Y_{t+h}-Y_{\text {Potential }}}{Y_{\text {Potential }}}$, where $Y_{\text {Potential }}$ is the trend predicted outcome at time $t$. The baseline results are fully maintained using this outcome definition. Lastly, Table 12 presents the core estimates using Driscoll-Kraay standard errors in the second-stage of the panel IV, which are less conservative than the region-clustered standard errors.

Narrowing down the aggregate effects to specific GDP components, the core driver of the large contemporaneous fiscal multilpier from an income approach seems to be changes in aggregate compensation to employees (entitled "wages" in the Table 8). Since data on hourly wages by region is not available, I include employment changes per population as an additional outcome variable. There does not seem to be a similar response by employment, suggesting most of the increase in compensation of employees is absorbed by increases in wages to existing workers, rather than new job creation. These results are consistent with a New-Keynesian model with both frictional unemployment and downward real wage rigidities, where a positive demand shock leads to countercyclical price markups.

Ideally, I would like to have a decomposition of GDP into all of its parts - in particular including consumption. Unfortunately, consumption cannot be included as an explicit component since the expenditure approach to GDP accounting is not used in the EU at the regional level (due to lack of collection of regional net export data). However, as an alternative I use disposable household income ${ }^{18}$.

Note that the impact on compensation of employees substantially surpasses that on overall GDP, especially in longer horizons, suggesting an offsetting negative effect on some other GDP component. Since no other of the components included in Table

\footnotetext{
${ }^{18}$ Assuming a constant MPC across the business cycle, consumption and disposable income series should track each other closely.
} 
8 quantitatively or qualitatively reveals such a negative effect, it is likely that a deterioration of regional current account positions (possibly following an increase in relative labor costs) could reconcile these results.

\section{Cross-regional spillover effects}

From a theoretical perspective, the existence of spillover effects of one region's spending on another's outcomes could lead to an underestimation of the true aggregate federal effect of regional government expenditures, if that spillover were positive. This scenario could be supported by an increase in import demand from the region receiving the positive expenditure shock (an aggregate demand story - Serrato and Wingender (forthcoming)) or by technological/knowledge/human capital transfers to interconnected regions in cases where government expenditures spur productivity improvements. The latter transmission channel is likely to be more relevant over non-contemporaneous horizons, as productivity-driven dynamics typically respond to public investment shocks with longer lags due to learning, research and time-tobuild delays (Alston et al. (2010)). Alternatively, negative spillovers could theoretically arise due to labor market competition among regions, for example, leading to an overestimation of the aggregate closed economy multiplier from the baseline domestic multiplier figures in Table 2. From a policy perspective, determining the existence of spillover effects fits within the discussion of transnational fiscal stimuli in light of the recent sovereign-debt crisis in Europe. In particular, in the presence of positive spillover effects and asymmetric business cycle conditions in different regions, a region with room for fiscal expansion and an acommodative monetary policy stance could choose to do so in order to stimulate import demand from a debt-constrained region undergoing a demand-driven recession - for example, Germany expanding its fiscal stance in order to boost Greece's current account position post-2010 (Elekdag and Muir (2014); Blanchard et al. (2015)).

The European Union does not have inter-regional bilateral trade surveys similar to the ones the US and Canada have conducted in recent decades. The closest existing matrix of bilateral trade between NUTS 2 regions in Europe is by Thissen et al. (2013), who constructed a social accounting matrix with the most likely trade 
flows between European regions consistent with national accounts. Using the ratio of import flows between regions as weights for spillover shocks (akin the methodology proposed by Auerbach and Gorodnichenko (2013)), I get the results in Table 9. In particular, I have created a bilateral trade weighted fiscal shock variable to estimate the impact of cross-regional spillovers. I first predict the instrumented own-region shock for every region and year (expenditure change instrumented by commitment change). Then for each region $j$, I compute a weighted average of fiscal shocks of other regions $k$ (excluding own-shock), weighted by the share of total imports by region $k$ coming from $j$ (so that the sum of weights is always $<1$ ). The second stage uses this trade-weighted shock variable as the key regressor, and standard errors are bootstrapped with resampling within region clusters to account for the measurement error induced by the estimated regressor in the first stage. The results are positive and significant up to the third horizon after a shock. Notice they are contemporaneously larger than own-shock multipliers, but in contrast to the latter, these results suggest spillover effects fizzle out over time, rather than accumulate. This is consistent with the existence of positive demand spillovers, and can be reconciled with the positive own-shock multipliers I find in this paper.

\section{Conclusion}

Using novel data on regional structural funds transfers from the European Commission, this paper provided empirical estimates of an open economy relative fiscal multiplier for the European Union. I proposed a solution to a key endogeneity concern pervasive across studies looking at the efficacy of these transfers as a form of fiscal stimulus, involving the use of internal annual commitments/targets by the federal authority as instruments for the actual expenditures (endogenous to local macroeconomic conditions, but also our shock variable of interest). I found a very large multiplier in the order of 1.7 contemporaneously and 4 cummulatively over a three-year period, suggesting there may be room for welfare improving redistributive fiscal transfers across European regions. In addition, I used a novel dataset on constructed bilateral trade flows between European Union regions to estimate the magnitude of what I found to be equally large (though dynamically different from 
domestic multiplier) spillover effects across regions.

However, this paper refrained from speaking to what are likely to be increasingly important differences in effectiveness of heterogeneous types of transfers - either across industrial sector composition, beneficiary characteristics, project objectives, or the institutional environment of the recipient region. More EU-wide micro-oriented analyses of the impact of federal public investments on specific beneficiary companies' employment and profitability performance relative to that of comparable nonbeneficiaries (along a similar path to that blazed by Greenstone et al. (2010) and Florio and Moretti (2014) should provide micro-founded evidence capable of reconciling some of the core aggregate findings presented here. Likewise, expansion of the present analysis to longer time periods for which detailed financing records exist may facilitate future research into the state-dependence of the core fiscal multipliers and spillover effects described. 


\section{References}

Alston, Julian M., Matthew A. Andersen, Jennifer S. James, and Philip G. Pardey, "Persistence Pays: U.S. Agricultural Productivity Growth and the Benefits from Public R\&D Spending," Natural Resource Management and Policy, 2010, 34 .

Auerbach, Alan J. and Yuriy Gorodnichenko, "Fiscal Multipliers in Recession and Expansion," in "Fiscal Policy after the Financial Crisis" NBER Chapters, National Bureau of Economic Research, Inc, National Bureau of Economic Research, Inc, May 2012, pp. 63-98.

_ and _, "Output Spillovers from Fiscal Policy," American Economic Review, American Economic Association, May 2013, 103 (3), 141-46.

Bargain, Olivier, Mathias Dolls, Clemens Fuest, Dirk Neumann, Andreas Peichl, Nico Pestel, and Sebastian Siegloch, "Fiscal union in Europe? Redistributive and stabilizing effects of a European tax-benefit system and fiscal equalization mechanism," Economic Policy, July 2013, 28 (75), 375-422.

Becker, Sascha O., Peter H. Egger, and Maximilian von Ehrlich, "Going NUTS: The effect of EU Structural Funds on regional performance," Journal of Public Economics, Elsevier, October 2010, 94 (9-10), 578-590.

_, _, and _, "Too much of a good thing? On the growth effects of the EU's regional policy," European Economic Review, Elsevier, 2012, 56 (4), 648-668.

_, _, and _, "Absorptive Capacity and the Growth and Investment Effects of Regional Transfers: A Regression Discontinuity Design with Heterogeneous Treatment Effects," American Economic Journal: Economic Policy, American Economic Association, November 2013, 5 (4), 29-77.

Bernanke, Ben S., Mark Gertler, and Simon Gilchrist, "The financial accelerator in a quantitative business cycle framework," in J. B. Taylor and M. Woodford, 
eds., Handbook of Macroeconomics, Vol. 1 of Handbook of Macroeconomics, Elsevier, 1999, chapter 21, pp. 1341-1393.

Beugelsdijk, Maaike and Sylvester C.W. Eijffinger, "The Effectiveness of Structural Policy in the European Union: An Empirical Analysis for the EU15 in 1995-2001," Journal of Common Market Studies, Wiley Blackwell, March 2005, $43(1), 37-51$.

Blanchard, Olivier and Roberto Perotti, "An Empirical Characterization Of The Dynamic Effects Of Changes In Government Spending And Taxes On Output," The Quarterly Journal of Economics, MIT Press, November 2002, 117 (4), 1329-1368.

_, Christopher J. Erceg, and Jesper Lindé, "Jump-Starting the Euro Area Recovery: Would a Rise in Core Fiscal Spending Help the Periphery?," Working Paper Series 304, Sveriges Riksbank (Central Bank of Sweden) July 2015.

Bruckner, Markus and Anita Tuladhar, "The Effectiveness of Government Expenditures during Crisis: Evidence from Regional Government Spending in Japan 1990-2000," School of Economics Working Papers, University of Adelaide, School of Economics 2011-10, University of Adelaide, School of Economics February 2011.

Chodorow-Reich, Gabriel, Laura Feiveson, Zachary Liscow, and William Gui Woolston, "Does State Fiscal Relief during Recessions Increase Employment? Evidence from the American Recovery and Reinvestment Act," American Economic Journal: Economic Policy, American Economic Association, August 2012, 4 (3), 118-45.

Clemens, Michael, Steven Radelet, and Rikhil Bhavnani, "Counting chickens when they hatch: The short-term effect of aid on growth," International Finance, EconWPA 2004.

Economides, George, Apostolis Philippopoulos, and Petros Varthalitis, "Monetary Union, Even Higher Integration, or Back to National Currencies?," Technical Report 2016. 
Ederveen, Sjef, Henri L .F. Groot, and Richard Nahuis, "Fertile Soil for Structural Funds?A Panel Data Analysis of the Conditional Effectiveness of European Cohesion Policy," Kyklos, Wiley Blackwell, Feb 2006, 59 (1), 17-42.

Elekdag, Selim and Dirk Muir, "Das Public Kapital; How Much Would Higher German Public Investment Help Germany and the Euro Area?," IMF Working Papers 14/227, International Monetary Fund December 2014.

European Commission, "General provisions ERDF - ESF - Cohesion Fund (20072013)," 2010.

_, "The European Fund for Strategic Investments (EFSI) Programme," http://ec. europa.eu/priorities/jobs-growth-investment/plan/efsi/index_en.htm 2015. Accessed: 2015-09-16.

Fatas, Antonio and Ilian Mihov, "The Effects of Fiscal Policy on Consumption and Employment: Theory and Evidence," CEPR Discussion Papers, C.E.P.R. Discussion Papers 2760, C.E.P.R. Discussion Papers April 2001.

Florio, Massimo and Luigi Moretti, "The Effect of Business Support on Employment in Manufacturing: Evidence from the European Union Structural Funds in Germany, Italy and Spain," European Planning Studies, 2014, 22 (9), 1802-1823.

Giavazzi, Francesco and Marco Pagano, "Can Severe Fiscal Contractions Be Expansionary? Tales of Two Small European Countries," in "NBER Macroeconomics Annual 1990, Volume 5" NBER Chapters, National Bureau of Economic Research, Inc, National Bureau of Economic Research, Inc, May 1990, pp. 75-122.

Grauwe, Paul De and Wim Vanhaverbeke, "Is Europe an Optimum Currency Area? Evidence from Regional Data," CEPR Discussion Papers 555, C.E.P.R. Discussion Papers 1991.

Greenstone, Michael, Richard Hornbeck, and Enrico Moretti, "Identifying Agglomeration Spillovers: Evidence from Winners and Losers of Large Plant Openings," Journal of Political Economy, June 2010, 118 (3), 536-598. 
Hall, Robert E., "By How Much Does GDP Rise If the Government Buys More Output?," Brookings Papers on Economic Activity, Economic Studies Program, The Brookings Institution, 2009, 40 (2 (Fall)), 183-249.

Heijman, Wim and Tobias Koch, "The allocation of financial resources of the EU Structural Funds and Cohesion Fund during the period 2007-2013," Agricultural Economics - Czech, 2011, 57 (2), 49-56.

Holland, Dawn and Jonathan Portes, "Self-defeating austerity?," National Institute Economic Review, October 2012, (222).

Ilzetzki, Ethan, Enrique G. Mendoza, and Carlos A. Vegh, "How big (small?) are fiscal multipliers?," Journal of Monetary Economics, Elsevier, 2013, 60 (2), 239-254.

Imbens, Guido W. and Thomas Lemieux, "Regression discontinuity designs: A guide to practice," Journal of Econometrics, Elsevier, February 2008, 142 (2), 615-635.

Kallstrom, John, "Pushing for Growth," Masters Thesis, Lund University 2014.

Mohl, Philipp and Tobias Hagen, "Do EU structural funds promote regional growth? New evidence from various panel data approaches," Regional Science and Urban Economics, Elsevier, September 2010, 40 (5), 353-365.

_ and _ , "Do EU structural funds promote regional employment? Evidence from dynamic panel data models," Working Paper Series, European Central Bank 1403, European Central Bank December 2011.

Nakamura, Emi and Jon Steinsson, "Fiscal Stimulus in a Monetary Union: Evidence from US Regions," American Economic Review, American Economic Association, March 2014, 104 (3), 753-92.

Nickell, Stephen J., "Biases in Dynamic Models with Fixed Effects," Econometrica, November 1981, 49 (6), 1417-26. 
Pellegrini, Guido, Flavia Terribile, Ornella Tarola, Teo Muccigrosso, and Federica Busillo, "Measuring the effects of European Regional Policy on economic growth: A regression discontinuity approach," Papers in Regional Science, 2013, 92 (1), 217-233.

Ramey, Valerie A., "Identifying Government Spending Shocks: It's all in the Timing," The Quarterly Journal of Economics, 2011, 126 (1), 1-50.

Sala-i-Martin, Xavier X., "Regional cohesion: Evidence and theories of regional growth and convergence," European Economic Review, Elsevier, June 1996, 40 (6), 1325-1352.

Serrato, Juan Carlos Suarez and Philippe Wingender, "Estimating Fiscal Local Multipliers," Econometrica, forthcoming.

Thissen, Mark, Frank van Oort, and Dario Diodato, "Integration and Convergence in Regional Europe: European Regional Trade Flows from 2000 to 2010," ERSA conference papers, European Regional Science Association 2013. 


\section{A Tables}

Table 1: Summary Statistics All regions (NUTS 2 level), 2000-2011

\begin{tabular}{|c|c|c|c|c|c|c|c|}
\hline Country & $\begin{array}{c}\text { Total } \\
\text { NUTS2 } \\
\text { Region } \\
\text { Count }\end{array}$ & Obj. 1 & Obj. 2 & $\begin{array}{l}\text { Expenditure } \\
\text { to GDP }(\%)\end{array}$ & $\begin{array}{l}\text { Committed } \\
\text { Funds to } \\
\text { GDP }(\%)\end{array}$ & $\begin{array}{c}\text { GDP } \\
\text { Growth }(\%)\end{array}$ & $\begin{array}{c}\text { Unemployment } \\
\text { Rate }(\%)\end{array}$ \\
\hline $\mathrm{AT}$ & 9 & 1 & 8 & 0.08 & 0.11 & 1.01 & 4.24 \\
\hline $\mathrm{BE}$ & 9 & 1 & 8 & 0.04 & 0.07 & 1.08 & 7.82 \\
\hline CY & 1 & 0 & 1 & 0.24 & 0.22 & 1.82 & 6.10 \\
\hline $\mathrm{CZ}$ & 8 & 7 & 1 & 0.53 & 1.84 & 4.24 & 7.25 \\
\hline $\mathrm{DE}$ & 38 & 8 & 30 & 0.12 & 0.19 & 0.61 & 7.99 \\
\hline DK & 1 & 0 & 1 & 0.02 & 0.03 & 0.82 & 5.35 \\
\hline $\mathrm{EE}$ & 1 & 1 & 0 & 0.93 & 1.20 & 6.03 & 10.31 \\
\hline $\mathrm{ES}$ & 18 & 11 & 7 & 0.65 & 1.24 & 1.46 & 14.10 \\
\hline FI & 5 & 2 & 3 & 0.08 & 0.13 & 1.40 & 8.41 \\
\hline FR & 26 & 6 & 20 & 0.16 & 0.29 & 0.83 & 11.37 \\
\hline GR & 13 & 13 & 0 & 1.17 & 2.02 & 0.81 & 12.53 \\
\hline $\mathrm{HU}$ & 7 & 7 & 0 & 1.51 & 2.83 & 0.66 & 8.42 \\
\hline IE & 2 & 2 & 0 & 0.19 & 0.30 & 3.00 & 7.92 \\
\hline $\mathrm{IT}$ & 20 & 7 & 13 & 0.22 & 0.40 & -0.35 & 9.19 \\
\hline LT & 1 & 1 & 0 & 1.03 & 1.35 & 9.00 & 11.93 \\
\hline LV & 1 & 1 & 0 & 0.94 & 1.36 & 7.18 & 12.29 \\
\hline $\mathrm{MT}$ & 1 & 1 & 0 & 0.42 & 0.93 & 1.68 & 6.72 \\
\hline NL & 10 & 1 & 9 & 0.03 & 0.05 & 1.48 & 4.02 \\
\hline PL & 16 & 16 & 0 & 0.78 & 1.38 & 2.51 & 13.91 \\
\hline $\mathrm{PT}$ & 7 & 7 & 0 & 1.46 & 2.92 & 1.59 & 8.89 \\
\hline SE & 6 & 3 & 3 & 0.07 & 0.10 & 1.93 & 7.12 \\
\hline SI & 1 & 1 & 0 & 0.34 & 0.59 & 0.08 & 6.68 \\
\hline SK & 4 & 3 & 1 & 0.58 & 1.12 & 4.62 & 14.19 \\
\hline UK & 33 & 5 & 28 & 0.07 & 0.12 & 1.43 & 5.85 \\
\hline Total & 238 & 105 & 133 & 0.36 & 0.68 & 1.32 & 8.98 \\
\hline
\end{tabular}

Number of regions with no missing data.

Obj.1/2 categorization as of 2006 .

The last four columns represent annual averages for each country during the 2000-2011 period. 
Table 2: Panel IV - Objective 1 only (NUTS 2 level), 2000-2011

\begin{tabular}{|c|c|c|c|c|c|c|c|c|c|}
\hline \multirow{3}{*}{ Annual shock to expenditures to GDP } & \multirow{2}{*}{$\begin{array}{c}\text { Anticipation } \\
\text { All }\end{array}$} & \multicolumn{2}{|c|}{ Contemporaneous } & \multicolumn{2}{|c|}{ 1st Lead } & \multicolumn{2}{|c|}{ 2nd Lead } & \multicolumn{2}{|c|}{ 3rd Lead } \\
\hline & & All I & Post-2006 & All $\mathrm{I}$ & Post-2006 & All & Post-2006 & All & Post-2006 \\
\hline & $\begin{array}{c}0.454 \\
(0.906)\end{array}$ & $\begin{array}{l}2.962^{* * *} \\
(0.670)\end{array}$ & $\begin{array}{l}3.137^{* * *} \\
(0.581)\end{array}$ & $\begin{array}{l}4.647^{* * *} \\
(1.574)\end{array}$ & $\begin{array}{l}5.101^{* * *} \\
(1.590)\end{array}$ & $\begin{array}{l}4.670^{* *} \\
(2.273)\end{array}$ & $\begin{array}{l}5.720^{* * *} \\
(1.916)\end{array}$ & $\begin{array}{l}6.776^{*} \\
(3.531)\end{array}$ & $\begin{array}{l}7.938^{* * *} \\
(2.643)\end{array}$ \\
\hline L.GDP growth & $\begin{array}{l}-0.022 \\
(0.047)\end{array}$ & $\begin{array}{c}0.023 \\
(0.043)\end{array}$ & $\begin{array}{c}0.024 \\
(0.062)\end{array}$ & $\begin{array}{l}-0.110^{*} \\
(0.059)\end{array}$ & $\begin{array}{l}-0.305^{* * *} \\
(0.086)\end{array}$ & $\begin{array}{c}-0.066 \\
(0.086)\end{array}$ & $\begin{array}{l}-0.176 \\
(0.231)\end{array}$ & $\begin{array}{l}-0.140 \\
(0.121)\end{array}$ & $\begin{array}{l}-0.168 \\
(0.200)\end{array}$ \\
\hline Education & $\begin{array}{l}-0.000 \\
(0.004)\end{array}$ & $\begin{array}{c}0.007 \\
(0.005)\end{array}$ & $\begin{array}{c}0.009 \\
(0.006)\end{array}$ & $\begin{array}{c}0.009 \\
(0.008)\end{array}$ & $\begin{array}{c}0.007 \\
(0.009)\end{array}$ & $\begin{array}{c}0.005 \\
(0.011)\end{array}$ & $\begin{array}{c}-0.004 \\
(0.012)\end{array}$ & $\begin{array}{c}0.001 \\
(0.015)\end{array}$ & $\begin{array}{l}-0.012 \\
(0.014)\end{array}$ \\
\hline Industry share & $\begin{array}{l}-0.020 \\
(0.016)\end{array}$ & $\begin{array}{c}0.023^{*} \\
(0.012)\end{array}$ & $\begin{array}{l}0.051^{* * *} \\
(0.018)\end{array}$ & $\begin{array}{c}0.018 \\
(0.025)\end{array}$ & $\begin{array}{l}0.069^{* *} \\
(0.031)\end{array}$ & $\begin{array}{l}-0.008 \\
(0.040)\end{array}$ & $\begin{array}{c}0.001 \\
(0.050)\end{array}$ & $\begin{array}{l}-0.013 \\
(0.055)\end{array}$ & $\begin{array}{c}0.020 \\
(0.058)\end{array}$ \\
\hline Public share & $\begin{array}{c}-0.012 \\
(0.010)\end{array}$ & $\begin{array}{l}-0.031^{* * *} \\
(0.008)\end{array}$ & $\begin{array}{l}* 0.033^{* *} \\
(0.014)\end{array}$ & $\begin{array}{l}-0.050^{* * * *} \\
(0.016)\end{array}$ & $\begin{array}{l}-0.048^{*} \\
(0.026)\end{array}$ & $\begin{array}{l}-0.041^{*} \\
(0.023)\end{array}$ & $\begin{array}{c}-0.001 \\
(0.033)\end{array}$ & $\begin{array}{l}-0.025 \\
(0.031)\end{array}$ & $\begin{array}{l}0.063^{* *} \\
(0.030)\end{array}$ \\
\hline $\mathrm{N}$ & 802 & 817 & 419 & 749 & 351 & 681 & 283 & 621 & 223 \\
\hline Clusters & 91 & 91 & 91 & 91 & 91 & 91 & 91 & 91 & 91 \\
\hline
\end{tabular}

Standard errors in parentheses

Includes year and country fixed effects.

Clustered s.e.s at NUTS 2 level.

The "anticipation" column presents estimates of the baseline multiplier for Objective 1 regions in the year preceding the shock, by setting the dependent

variable as $\frac{Y_{i, t-1}-Y_{i, t-2}}{Y_{i, t-2}}$.

${ }_{p}<0.1, * *<<0.05, * * *<0.01$

Table 3: Panel IV - Objective 1 vs 2 (NUTS 2 level), 2000-2011

\begin{tabular}{|c|c|c|c|c|c|c|c|c|}
\hline & \multicolumn{2}{|c|}{ Contemporaneous } & \multicolumn{2}{|c|}{ 1st Lead } & \multicolumn{2}{|c|}{ 2nd Lead } & \multicolumn{2}{|c|}{ 3rd Lead } \\
\hline & Obj. 1 & Obj. 2 & Obj. 1 & Obj. 2 & Obj. 1 & Obj. 2 & Obj. 1 & Obj. 2 \\
\hline Annual shock to expenditures to GDP & $\begin{array}{l}2.962^{* * *} \\
(0.670)\end{array}$ & $\begin{array}{c}5.141 \\
(4.378)\end{array}$ & $\begin{array}{l}4.647^{* *} \\
(1.574)\end{array}$ & $\begin{array}{r}{ }^{*}-3.317 \\
(8.252)\end{array}$ & $\begin{array}{c}4.670^{* *} \\
(2.273)\end{array}$ & $\begin{array}{c}-2.776 \\
(11.926)\end{array}$ & $\begin{array}{r}6.776^{*} \\
(3.531)\end{array}$ & $\begin{array}{c}8.619 \\
(22.013)\end{array}$ \\
\hline L.GDP growth & $\begin{array}{c}0.023 \\
(0.043)\end{array}$ & $\begin{array}{l}0.115^{* * *} \\
(0.041)\end{array}$ & $\begin{array}{l}-0.110^{*} \\
(0.059)\end{array}$ & $\begin{array}{l}-0.048 \\
(0.068)\end{array}$ & $\begin{array}{l}-0.066 \\
(0.086)\end{array}$ & $\begin{array}{l}-0.015 \\
(0.077)\end{array}$ & $\begin{array}{l}-0.140 \\
(0.121)\end{array}$ & $\begin{array}{l}-0.014 \\
(0.119)\end{array}$ \\
\hline Education & $\begin{array}{c}0.007 \\
(0.005)\end{array}$ & $\begin{array}{l}-0.003 \\
(0.006)\end{array}$ & $\begin{array}{c}0.009 \\
(0.008)\end{array}$ & $\begin{array}{l}-0.001 \\
(0.012)\end{array}$ & $\begin{array}{c}0.005 \\
(0.011)\end{array}$ & $\begin{array}{c}0.011 \\
(0.016)\end{array}$ & $\begin{array}{c}0.001 \\
(0.015)\end{array}$ & $\begin{array}{c}0.034^{*} \\
(0.017)\end{array}$ \\
\hline Industry share & $\begin{array}{c}0.023^{*} \\
(0.012)\end{array}$ & $\begin{array}{l}0.023^{* * *} \\
(0.008)\end{array}$ & $\begin{array}{c}0.018 \\
(0.025)\end{array}$ & $\begin{array}{c}0.041^{* *} \\
(0.018)\end{array}$ & $\begin{array}{l}-0.008 \\
(0.040)\end{array}$ & $\begin{array}{c}0.056^{* *} \\
(0.027)\end{array}$ & $\begin{array}{l}-0.013 \\
(0.055)\end{array}$ & $\begin{array}{c}0.084^{* *} \\
(0.035)\end{array}$ \\
\hline Public share & $\begin{array}{l}-0.031^{* * *} \\
(0.008)\end{array}$ & $\begin{array}{c}* 0.007 \\
(0.008)\end{array}$ & $\begin{array}{l}-0.050^{*} \\
(0.016)\end{array}$ & $\begin{array}{l}* 0.022 \\
(0.021)\end{array}$ & $\begin{array}{l}-0.041^{*} \\
(0.023)\end{array}$ & $\begin{array}{c}0.039 \\
(0.033)\end{array}$ & $\begin{array}{l}-0.025 \\
(0.031)\end{array}$ & $\begin{array}{c}0.034 \\
(0.038)\end{array}$ \\
\hline $\mathrm{N}$ & 817 & 1305 & 749 & 1174 & 681 & 1049 & 621 & 923 \\
\hline Clusters & 91 & 135 & 91 & 135 & 91 & 135 & 91 & 135 \\
\hline $\begin{array}{l}\text { Standard errors in parentheses } \\
\text { Includes year and country fixed effects. } \\
\text { Clustered s.e.s at NUTS } 2 \text { level. } \\
*_{p}<0.1, * *^{*}<0.05,{ }^{*}{ }^{*}<0.01\end{array}$ & & & & & & & & \\
\hline
\end{tabular}


Table 4: Panel IV - Objective 1 regions: All vs EU-12 (NUTS 2 level), 2000-2011

\begin{tabular}{|c|c|c|c|c|c|c|c|c|}
\hline \multirow{4}{*}{ Annual shock to expenditures to GDP } & \multicolumn{2}{|c|}{ Contemporaneous } & \multicolumn{2}{|c|}{ 1st Lead } & \multicolumn{2}{|c|}{ 2nd Lead } & \multicolumn{2}{|c|}{ 3rd Lead } \\
\hline & All E & EU-12 only & \multicolumn{2}{|c|}{ All EU-12 only } & \multicolumn{2}{|c|}{ All EU-12 only } & All & EU-12 only \\
\hline & $2.962^{* * *}$ & $2.073^{* * *}$ & $4.647^{* * *}$ & $3.462^{* * *}$ & $4.670^{* *}$ & $4.486^{* *}$ & $6.776^{*}$ & $6.636^{*}$ \\
\hline & $(0.670)$ & $(0.709)$ & $(1.574)$ & $(1.331)$ & $(2.273)$ & $(2.003)$ & $(3.531)$ & $(3.487)$ \\
\hline L.GDP growth & 0.023 & 0.098 & $-0.110^{*}$ & 0.090 & -0.066 & 0.150 & -0.140 & $0.285^{* * *}$ \\
\hline & $(0.043)$ & $(0.063)$ & $(0.059)$ & $(0.091)$ & $(0.086)$ & $(0.110)$ & $(0.121)$ & $(0.107)$ \\
\hline Education & 0.007 & -0.002 & 0.009 & -0.004 & 0.005 & -0.010 & 0.001 & -0.017 \\
\hline & $(0.005)$ & $(0.003)$ & $(0.008)$ & $(0.007)$ & $(0.011)$ & $(0.013)$ & $(0.015)$ & $(0.018)$ \\
\hline Industry share & $0.023^{*}$ & 0.016 & 0.018 & 0.020 & -0.008 & 0.014 & -0.013 & 0.024 \\
\hline & $(0.012)$ & $(0.012)$ & $(0.025)$ & $(0.026)$ & $(0.040)$ & $(0.040)$ & $(0.055)$ & $(0.057)$ \\
\hline Public share & $-0.031^{* * *}$ & $-0.016^{* * *}$ & $-0.050 * * *$ & $-0.030^{* *}$ & $-0.041^{*}$ & -0.019 & -0.025 & -0.002 \\
\hline & $(0.008)$ & $(0.005)$ & $(0.016)$ & $(0.012)$ & $(0.023)$ & $(0.020)$ & $(0.031)$ & $(0.029)$ \\
\hline $\mathrm{N}$ & 817 & 585 & 749 & 542 & 681 & 499 & 621 & 455 \\
\hline Clusters & 91 & 60 & 91 & 60 & 91 & 60 & 91 & 60 \\
\hline
\end{tabular}

Standard errors in parentheses

Includes year and country fixed effects.

Clustered s.e.s at NUTS 2 level.

${ }^{*} p<0.1,{ }^{*}{ }^{*}<0.05,{ }^{* *}{ }^{*}<0.01$

Table 5: Panel IV - Objective 1 only (NUTS 2 level), 2000-2011 Unemployment

\begin{tabular}{|c|c|c|c|c|c|c|c|c|}
\hline & \multicolumn{2}{|c|}{ Contemporaneous } & \multicolumn{2}{|c|}{ 1st Lead } & \multicolumn{2}{|c|}{ 2nd Lead } & \multicolumn{2}{|c|}{ 3rd Lead } \\
\hline & All & Post-2006 & All & Post-2006 & All & Post-2006 & All & Post-2006 \\
\hline Annual shock to expenditures to GDP & $\begin{array}{l}-0.167 \\
(0.437)\end{array}$ & $\begin{array}{c}-0.390 \\
(0.405)\end{array}$ & $\begin{array}{l}-0.717 \\
(0.849)\end{array}$ & $\begin{array}{l}-1.255 \\
(0.858)\end{array}$ & $\begin{array}{l}-1.236 \\
(1.234)\end{array}$ & $\begin{array}{l}-2.193^{*} \\
(1.180)\end{array}$ & $\begin{array}{l}-1.454 \\
(1.920)\end{array}$ & $\begin{array}{l}-3.481^{*} \\
(1.954)\end{array}$ \\
\hline L.Unemployment rate change & $\begin{array}{c}0.057 \\
(0.046)\end{array}$ & $\begin{array}{l}0.200^{* * *} \\
(0.054)\end{array}$ & $\begin{array}{c}0.093 \\
(0.069)\end{array}$ & $\begin{array}{c}0.128 \\
(0.087)\end{array}$ & $\begin{array}{l}-0.008 \\
(0.098)\end{array}$ & $\begin{array}{l}-0.115 \\
(0.143)\end{array}$ & $\begin{array}{l}-0.203 \\
(0.126)\end{array}$ & $\begin{array}{l}-0.350 \\
(0.219)\end{array}$ \\
\hline Education & $\begin{array}{l}-0.001 \\
(0.002)\end{array}$ & $\begin{array}{c}0.001 \\
(0.001)\end{array}$ & $\begin{array}{l}-0.002 \\
(0.004)\end{array}$ & $\begin{array}{c}0.001 \\
(0.003)\end{array}$ & $\begin{array}{l}-0.000 \\
(0.006)\end{array}$ & $\begin{array}{c}0.000 \\
(0.004)\end{array}$ & $\begin{array}{c}0.001 \\
(0.008)\end{array}$ & $\begin{array}{l}-0.000 \\
(0.006)\end{array}$ \\
\hline Industry share & $\begin{array}{c}0.005 \\
(0.007)\end{array}$ & $\begin{array}{c}-0.002 \\
(0.006)\end{array}$ & $\begin{array}{c}0.012 \\
(0.013)\end{array}$ & $\begin{array}{l}-0.000 \\
(0.011)\end{array}$ & $\begin{array}{c}0.029^{*} \\
(0.017)\end{array}$ & $\begin{array}{c}0.004 \\
(0.017)\end{array}$ & $\begin{array}{c}0.037 \\
(0.023)\end{array}$ & $\begin{array}{c}0.007 \\
(0.023)\end{array}$ \\
\hline Public share & $\begin{array}{c}0.017^{*} \\
(0.009)\end{array}$ & $\begin{array}{c}0.001 \\
(0.006)\end{array}$ & $\begin{array}{l}0.041^{* *} \\
(0.017)\end{array}$ & $\begin{array}{c}0.020^{*} \\
(0.011)\end{array}$ & $\begin{array}{l}0.054^{* *} \\
(0.022)\end{array}$ & $\begin{array}{c}0.029 \\
(0.019)\end{array}$ & $\begin{array}{c}0.067^{* *} \\
(0.029)\end{array}$ & $\begin{array}{c}0.035 \\
(0.027)\end{array}$ \\
\hline $\mathrm{N}$ & 861 & 517 & 861 & 517 & 862 & 517 & 779 & 433 \\
\hline Clusters & 103 & 103 & 103 & 103 & 103 & 103 & 103 & 103 \\
\hline
\end{tabular}

Standard errors in parentheses

Includes year and country fixed effects.

Clustered s.e.s at NUTS 2 level.

${ }^{*} p<0.1, * *<0.05, * * *<0.01$ 
Table 6: Panel IV - Objective 1 vs 2 (NUTS 2 level), 2000-2011

Unemployment

\begin{tabular}{|c|c|c|c|c|c|c|c|c|}
\hline & \multicolumn{2}{|c|}{ Contemporaneous } & \multicolumn{2}{|c|}{ 1st Lead } & \multicolumn{2}{|c|}{ 2nd Lead } & \multicolumn{2}{|c|}{ 3rd Lead } \\
\hline & Obj. 1 & Obj. 2 & Obj. 1 & Obj. 2 & Obj. 1 & Obj. 2 & Obj. 1 & Obj. 2 \\
\hline Annual shock to expenditures to GDP & $\begin{array}{l}-0.167 \\
(0.437)\end{array}$ & $\begin{array}{l}-4.893^{\text {** }} \\
(1.932)\end{array}$ & $\begin{array}{l}-0.717 \\
(0.849)\end{array}$ & $\begin{array}{l}-5.222 \\
(3.754)\end{array}$ & $\begin{array}{l}-1.236 \\
(1.234)\end{array}$ & $\begin{array}{l}-0.858 \\
(4.919)\end{array}$ & $\begin{array}{l}-1.454 \\
(1.920)\end{array}$ & $\begin{array}{c}5.131 \\
(5.448)\end{array}$ \\
\hline L. Unemployment rate change & $\begin{array}{c}0.057 \\
(0.046)\end{array}$ & $\begin{array}{c}0.042 \\
(0.037)\end{array}$ & $\begin{array}{c}0.093 \\
(0.069)\end{array}$ & $\begin{array}{c}0.129^{* *} \\
(0.055)\end{array}$ & $\begin{array}{l}-0.008 \\
(0.098)\end{array}$ & $\begin{array}{c}0.165^{* *} \\
(0.070)\end{array}$ & $\begin{array}{l}-0.203 \\
(0.126)\end{array}$ & $\begin{array}{c}0.071 \\
(0.080)\end{array}$ \\
\hline Education & $\begin{array}{l}-0.001 \\
(0.002)\end{array}$ & $\begin{array}{c}0.000 \\
(0.001)\end{array}$ & $\begin{array}{l}-0.002 \\
(0.004)\end{array}$ & $\begin{array}{c}-0.001 \\
(0.002)\end{array}$ & $\begin{array}{l}-0.000 \\
(0.006)\end{array}$ & $\begin{array}{l}-0.004 \\
(0.003)\end{array}$ & $\begin{array}{c}0.001 \\
(0.008)\end{array}$ & $\begin{array}{l}-0.005 \\
(0.004)\end{array}$ \\
\hline Industry share & $\begin{array}{c}0.005 \\
(0.007)\end{array}$ & $\begin{array}{l}-0.002 \\
(0.003)\end{array}$ & $\begin{array}{c}0.012 \\
(0.013)\end{array}$ & $\begin{array}{l}-0.005 \\
(0.006)\end{array}$ & $\begin{array}{c}0.029^{*} \\
(0.017)\end{array}$ & $\begin{array}{l}-0.006 \\
(0.009)\end{array}$ & $\begin{array}{c}0.037 \\
(0.023)\end{array}$ & $\begin{array}{l}-0.007 \\
(0.011)\end{array}$ \\
\hline Public share & $\begin{array}{r}0.017^{*} \\
(0.009)\end{array}$ & $\begin{array}{l}-0.003 \\
(0.002)\end{array}$ & $\begin{array}{l}0.041^{* *} \\
(0.017)\end{array}$ & $\begin{array}{c}-0.006 \\
(0.005)\end{array}$ & $\begin{array}{c}0.054^{* *} \\
(0.022)\end{array}$ & $\begin{array}{l}-0.011^{*} \\
(0.007)\end{array}$ & $\begin{array}{l}0.067^{* *} \\
(0.029)\end{array}$ & $\begin{array}{l}-0.016^{*} \\
(0.009)\end{array}$ \\
\hline $\mathrm{N}$ & 861 & 1538 & 861 & 1539 & 862 & 1539 & 779 & 1378 \\
\hline Clusters & 103 & 166 & 103 & 166 & 103 & 166 & 103 & 166 \\
\hline
\end{tabular}

Standard errors in parentheses

Includes year and country fixed effects.

Clustered s.e.s at NUTS 2 level.

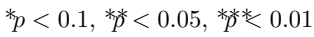

Table 7: Panel IV - Objective 1 regions: All vs EU-12 (NUTS 2 level), 2000-2011 Unemployment

\begin{tabular}{|c|c|c|c|c|c|c|c|c|}
\hline & \multicolumn{2}{|c|}{ Contemporaneous } & \multicolumn{2}{|c|}{ 1st Lead } & \multicolumn{2}{|c|}{ 2nd Lead } & \multicolumn{2}{|c|}{ 3rd Lead } \\
\hline & All & EU-12 only & All & EU-12 only & All & EU-12 only & All & EU-12 only \\
\hline Annual shock to expenditures to GDP & $\begin{array}{l}-0.167 \\
(0.437)\end{array}$ & $\begin{array}{c}0.144 \\
(0.681)\end{array}$ & $\begin{array}{c}-0.717 \\
(0.849)\end{array}$ & $\begin{array}{c}0.237 \\
(1.052)\end{array}$ & $\begin{array}{l}-1.236 \\
(1.234)\end{array}$ & $\begin{array}{c}0.243 \\
(1.259)\end{array}$ & $\begin{array}{c}-1.454 \\
(1.920)\end{array}$ & $\begin{array}{c}-0.427 \\
(1.534)\end{array}$ \\
\hline L.Unemployment rate change & $\begin{array}{c}0.057 \\
(0.046)\end{array}$ & $\begin{array}{c}0.026 \\
(0.062)\end{array}$ & $\begin{array}{c}0.093 \\
(0.069)\end{array}$ & $\begin{array}{c}0.162^{*} \\
(0.086)\end{array}$ & $\begin{array}{l}-0.008 \\
(0.098)\end{array}$ & $\begin{array}{c}0.136 \\
(0.114)\end{array}$ & $\begin{array}{l}-0.203 \\
(0.126)\end{array}$ & $\begin{array}{c}0.014 \\
(0.130)\end{array}$ \\
\hline Education & $\begin{array}{l}-0.001 \\
(0.002)\end{array}$ & $\begin{array}{l}-0.007^{*} \\
(0.004)\end{array}$ & $\begin{array}{c}-0.002 \\
(0.004)\end{array}$ & $\begin{array}{c}-0.014^{*} \\
(0.008)\end{array}$ & $\begin{array}{l}-0.000 \\
(0.006)\end{array}$ & $\begin{array}{l}-0.016 \\
(0.013)\end{array}$ & $\begin{array}{c}0.001 \\
(0.008)\end{array}$ & $\begin{array}{c}-0.016 \\
(0.017)\end{array}$ \\
\hline Industry share & $\begin{array}{c}0.005 \\
(0.007)\end{array}$ & $\begin{array}{c}-0.004 \\
(0.010)\end{array}$ & $\begin{array}{c}0.012 \\
(0.013)\end{array}$ & $\begin{array}{c}0.004 \\
(0.015)\end{array}$ & $\begin{array}{c}0.029^{*} \\
(0.017)\end{array}$ & $\begin{array}{c}0.042 \\
(0.027)\end{array}$ & $\begin{array}{c}0.037 \\
(0.023)\end{array}$ & $\begin{array}{c}0.046 \\
(0.035)\end{array}$ \\
\hline Public share & $\begin{array}{c}0.017^{*} \\
(0.009)\end{array}$ & $\begin{array}{l}0.036^{* * *} \\
(0.011)\end{array}$ & $\begin{array}{c}0.041^{* *} \\
(0.017)\end{array}$ & $\begin{array}{l}0.074^{* * *} \\
(0.018)\end{array}$ & $\begin{array}{l}0.054^{* *} \\
(0.022)\end{array}$ & $\begin{array}{c}0.085^{* *} \\
(0.033)\end{array}$ & $\begin{array}{l}0.067^{* *} \\
(0.029)\end{array}$ & $\begin{array}{c}0.106^{* *} \\
(0.044)\end{array}$ \\
\hline $\mathrm{N}$ & 861 & 498 & 861 & 498 & 862 & 499 & 779 & 456 \\
\hline Clusters & 103 & 56 & 103 & 56 & 103 & 56 & 103 & 56 \\
\hline
\end{tabular}

Standard errors in parentheses

Includes year and country fixed effects.

Clustered s.e.s at NUTS 2 level.

${ }^{*} p<0.1,{ }^{*}{ }^{*}<0.05,{ }^{*}{ }^{*}{ }^{*}<0.01$ 


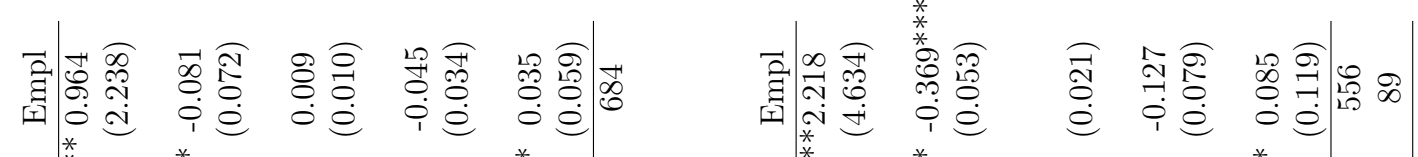

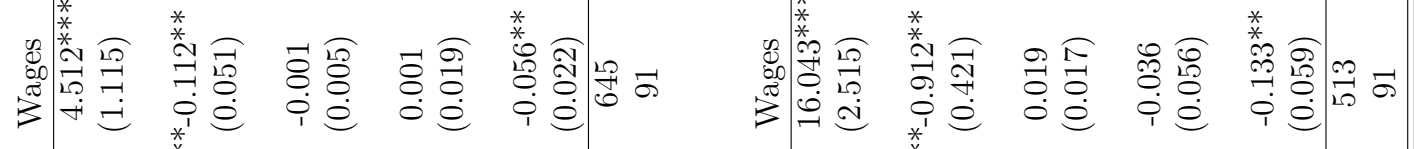

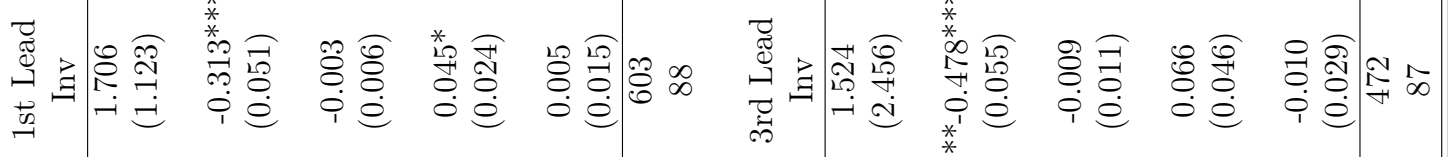

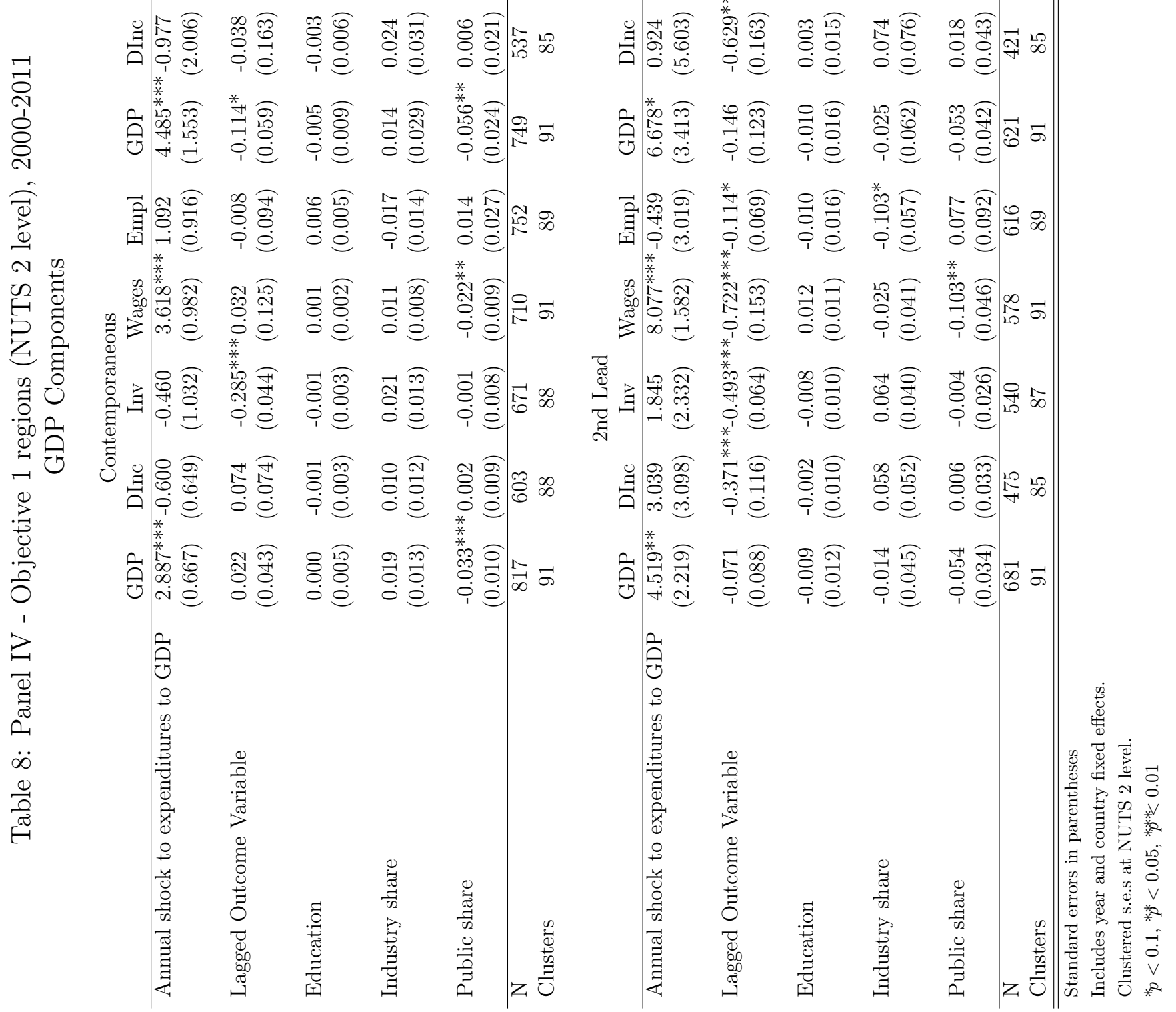


Table 9: Panel IV - All regions (NUTS 2 level, all objectives), 2000-2011 Import-weighted fiscal spillovers

\begin{tabular}{lcccc} 
& Contemporaneous & 1st Lead & 2nd Lead & 3rd Lead \\
\hline Import-weighted fiscal shock & $3.949^{* * *}$ & $3.103^{* * *}$ & $5.841^{* * *}$ & $1.914^{*}$ \\
& $(1.058)$ & $(0.719)$ & $(1.640)$ & $(0.983)$ \\
& & & & \\
L.GDP growth & $0.071^{* * *}$ & $-0.083^{* * *}$ & $0.091^{* * *}$ & $-0.035^{*}$ \\
& $(0.014)$ & $(0.020)$ & $(0.025)$ & $(0.019)$ \\
Education & -0.003 & 0.005 & -0.001 & 0.001 \\
& $(0.005)$ & $(0.004)$ & $(0.003)$ & $(0.003)$ \\
Industry share & -0.002 & -0.010 & 0.007 & 0.007 \\
& $(0.010)$ & $(0.009)$ & $(0.010)$ & $(0.008)$ \\
Public share & & & & \\
& 0.012 & 0.001 & 0.007 & 0.006 \\
\hline N & $(0.013)$ & $(0.010)$ & $(0.008)$ & $(0.008)$ \\
\hline Clusters & 2613 & 2377 & 2149 & 1956 \\
\hline \hline
\end{tabular}

Standard errors in parentheses

Includes year and country fixed effects.

Weighted fiscal shock measure excludes own-region shock.

Standard errors are bootstrapped with resampling within NUTS 2 level clusters.

${ }^{*} p<0.1, *^{*}<0.05,{ }^{* * *}{ }^{*} 0.01$ 


\section{A.1 Robustness checks}

Table 10: Panel IV - Objective 1 only (NUTS 2 level), 2000-2011

RHS: Spending levels

\begin{tabular}{|c|c|c|c|c|c|c|c|c|}
\hline \multirow{3}{*}{ Annual expenditures to GDP } & \multicolumn{2}{|c|}{ Contemporaneous } & \multicolumn{2}{|c|}{ 1st Lead } & \multicolumn{2}{|c|}{ 2nd Lead } & \multicolumn{2}{|c|}{ 3rd Lead } \\
\hline & All & Post-2006 & All I & Post-2006 & All & Post-2006 & All & Post-2006 \\
\hline & $\begin{array}{l}4.586^{* * *} \\
(1.308)\end{array}$ & $\begin{array}{c}2.593 \\
(2.130)\end{array}$ & $\begin{array}{l}6.399^{* * *} \\
(2.354)\end{array}$ & $\begin{array}{c}9.616 \\
(6.671)\end{array}$ & $\begin{array}{c}5.646^{* *} \\
(2.878)\end{array}$ & $\begin{array}{l}10.092^{* * *} \\
(3.683)\end{array}$ & $\begin{array}{c}-8.695 \\
(18.187)\end{array}$ & $\begin{array}{c}-13.460 \\
(12.311)\end{array}$ \\
\hline L.GDP growth & $\begin{array}{c}0.099^{*} \\
(0.055)\end{array}$ & $\begin{array}{c}0.044 \\
(0.059)\end{array}$ & $\begin{array}{l}-0.107 \\
(0.082)\end{array}$ & $\begin{array}{l}-0.217^{* *} \\
(0.094)\end{array}$ & $\begin{array}{l}-0.031 \\
(0.131)\end{array}$ & $\begin{array}{c}0.192 \\
(0.293)\end{array}$ & $\begin{array}{l}-0.426 \\
(0.509)\end{array}$ & $\begin{array}{c}-0.769 \\
(0.468)\end{array}$ \\
\hline Education & $\begin{array}{c}0.006 \\
(0.006)\end{array}$ & $\begin{array}{c}0.010 \\
(0.007)\end{array}$ & $\begin{array}{c}0.000 \\
(0.012)\end{array}$ & $\begin{array}{c}0.001 \\
(0.014)\end{array}$ & $\begin{array}{l}-0.010 \\
(0.016)\end{array}$ & $\begin{array}{l}-0.017 \\
(0.017)\end{array}$ & $\begin{array}{l}-0.011 \\
(0.026)\end{array}$ & $\begin{array}{c}0.015 \\
(0.032)\end{array}$ \\
\hline Industry share & $\begin{array}{c}0.016 \\
(0.015)\end{array}$ & $\begin{array}{l}0.061^{* * *} \\
(0.023)\end{array}$ & $\begin{array}{l}-0.025 \\
(0.038)\end{array}$ & $\begin{array}{c}0.023 \\
(0.066)\end{array}$ & $\begin{array}{l}-0.045 \\
(0.055)\end{array}$ & $\begin{array}{l}-0.068 \\
(0.068)\end{array}$ & $\begin{array}{l}-0.075 \\
(0.071)\end{array}$ & $\begin{array}{c}0.203 \\
(0.170)\end{array}$ \\
\hline Public share & $\begin{array}{l}-0.032^{* *} \\
(0.015)\end{array}$ & $\begin{array}{l}-0.041^{*} \\
(0.023)\end{array}$ & $\begin{array}{c}-0.034 \\
(0.026)\end{array}$ & $\begin{array}{l}-0.016 \\
(0.048)\end{array}$ & $\begin{array}{l}-0.022 \\
(0.033)\end{array}$ & $\begin{array}{c}0.055 \\
(0.053)\end{array}$ & $\begin{array}{l}-0.067 \\
(0.072)\end{array}$ & $\begin{array}{c}-0.084 \\
(0.142)\end{array}$ \\
\hline $\mathrm{N}$ & 787 & 419 & 719 & 351 & 651 & 283 & 591 & 223 \\
\hline Clusters & 91 & 91 & 91 & 91 & 91 & 91 & 91 & 91 \\
\hline
\end{tabular}

Standard errors in parentheses

Includes year and country fixed effects.

3 lags of spending levels are also included on the right hand-side

to control for autocorrelation.

Clustered s.e.s at NUTS 2 level.

${ }^{*} p<0.1,{ }^{*}<0.05$, *** 20.01 
Table 11: Panel IV - Objective 1 only (NUTS 2 level), 2000-2011

LHS: Percentage output gap

\begin{tabular}{|c|c|c|c|c|c|c|c|c|}
\hline \multirow{3}{*}{ Annual expenditures to potential GDP } & \multicolumn{2}{|c|}{ Contemporaneous } & \multicolumn{2}{|c|}{ 1st Lead } & \multicolumn{2}{|c|}{ 2nd Lead } & \multicolumn{2}{|c|}{ 3rd Lead } \\
\hline & All I & Post-2006 & All I & Post-2006 & All & Post-2006 & All & Post-2006 \\
\hline & $\begin{array}{l}2.059^{* * *} \\
(0.712)\end{array}$ & $\begin{array}{l}2.398^{* * *} \\
(0.597)\end{array}$ & $\begin{array}{c}2.968^{* *} \\
(1.319)\end{array}$ & $\begin{array}{c}2.732^{* * *} \\
(1.028)\end{array}$ & $\begin{array}{c}3.731^{* *} \\
(1.701)\end{array}$ & $\begin{array}{c}3.134^{* *} \\
(1.259)\end{array}$ & $\begin{array}{c}5.377^{*} \\
(2.844)\end{array}$ & $\begin{array}{c}5.065^{* *} \\
(2.005)\end{array}$ \\
\hline L.Percentage Output Gap & $\begin{array}{l}0.811^{* * *} \\
(0.033)\end{array}$ & $\begin{array}{l}0.821^{* * *} \\
(0.049)\end{array}$ & $\begin{array}{l}0.429^{* * *} \\
(0.054)\end{array}$ & $\begin{array}{l}0.331^{* * *} \\
(0.067)\end{array}$ & $\begin{array}{c}0.079 \\
(0.077)\end{array}$ & $\begin{array}{c}0.028 \\
(0.081)\end{array}$ & $\begin{array}{l}-0.323^{* * *} \\
(0.102)\end{array}$ & $* \begin{array}{c}-0.002 \\
(0.096)\end{array}$ \\
\hline Education & $\begin{array}{c}0.005 \\
(0.003)\end{array}$ & $\begin{array}{c}0.005 \\
(0.005)\end{array}$ & $\begin{array}{c}0.007^{*} \\
(0.004)\end{array}$ & $\begin{array}{c}0.003 \\
(0.006)\end{array}$ & $\begin{array}{c}0.007 \\
(0.006)\end{array}$ & $\begin{array}{l}-0.000 \\
(0.007)\end{array}$ & $\begin{array}{c}0.011 \\
(0.009)\end{array}$ & $\begin{array}{l}-0.002 \\
(0.008)\end{array}$ \\
\hline Industry share & $\begin{array}{l}0.034^{* * *} \\
(0.009)\end{array}$ & $\begin{array}{l}0.068^{* * *} \\
(0.017)\end{array}$ & $\begin{array}{c}0.013 \\
(0.022)\end{array}$ & $\begin{array}{l}0.066^{* * *} \\
(0.024)\end{array}$ & $\begin{array}{l}-0.025 \\
(0.038)\end{array}$ & $\begin{array}{l}-0.002 \\
(0.032)\end{array}$ & $\begin{array}{l}-0.065 \\
(0.054)\end{array}$ & $\begin{array}{l}-0.002 \\
(0.039)\end{array}$ \\
\hline Public share & $\begin{array}{l}-0.028^{* * *} \\
(0.006)\end{array}$ & $\begin{array}{l}{ }^{*}-0.032^{* *} \\
(0.014)\end{array}$ & $\begin{array}{l}-0.036^{* * *} \\
(0.011)\end{array}$ & $\begin{array}{c}-0.039 * \\
(0.021)\end{array}$ & $\begin{array}{l}-0.029 \\
(0.018)\end{array}$ & $\begin{array}{l}-0.014 \\
(0.025)\end{array}$ & $\begin{array}{l}-0.015 \\
(0.025)\end{array}$ & $\begin{array}{c}0.029 \\
(0.019)\end{array}$ \\
\hline $\mathrm{N}$ & 832 & 419 & 764 & 351 & 696 & 283 & 636 & 223 \\
\hline Clusters & 91 & 91 & 91 & 91 & 91 & 91 & 91 & 91 \\
\hline
\end{tabular}

Standard errors in parentheses

Includes year and country fixed effects.

Clustered s.e.s at NUTS 2 level.

${ }^{*} p<0.1,{ }^{*} *<0.05,{ }^{*} *{ }^{*}<0.01$ 
Table 12: Panel IV - Objective 1 only (NUTS 2 level), 2000-2011 Driscoll-Kraay robust standard errors

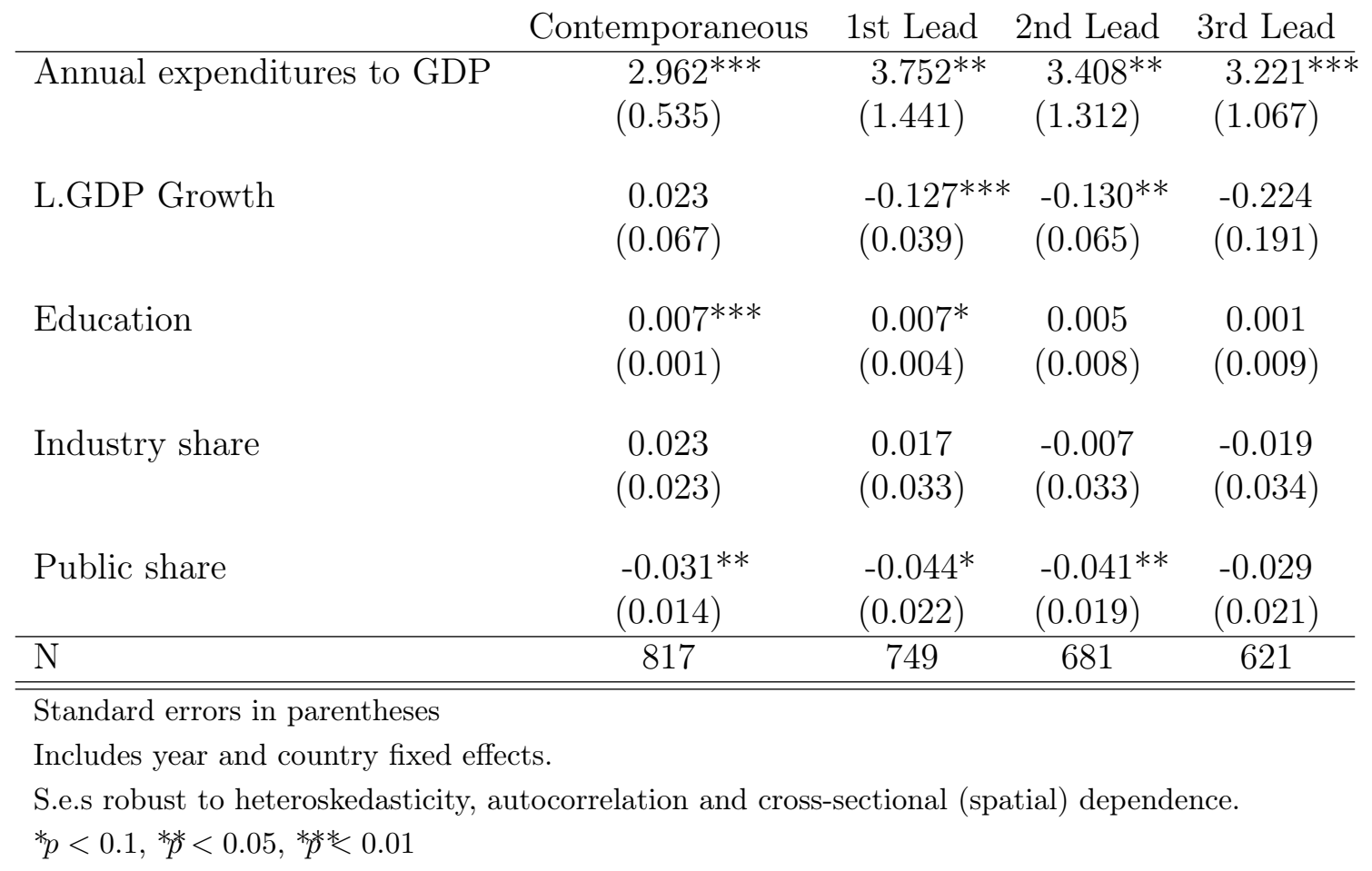




\section{B Figures}
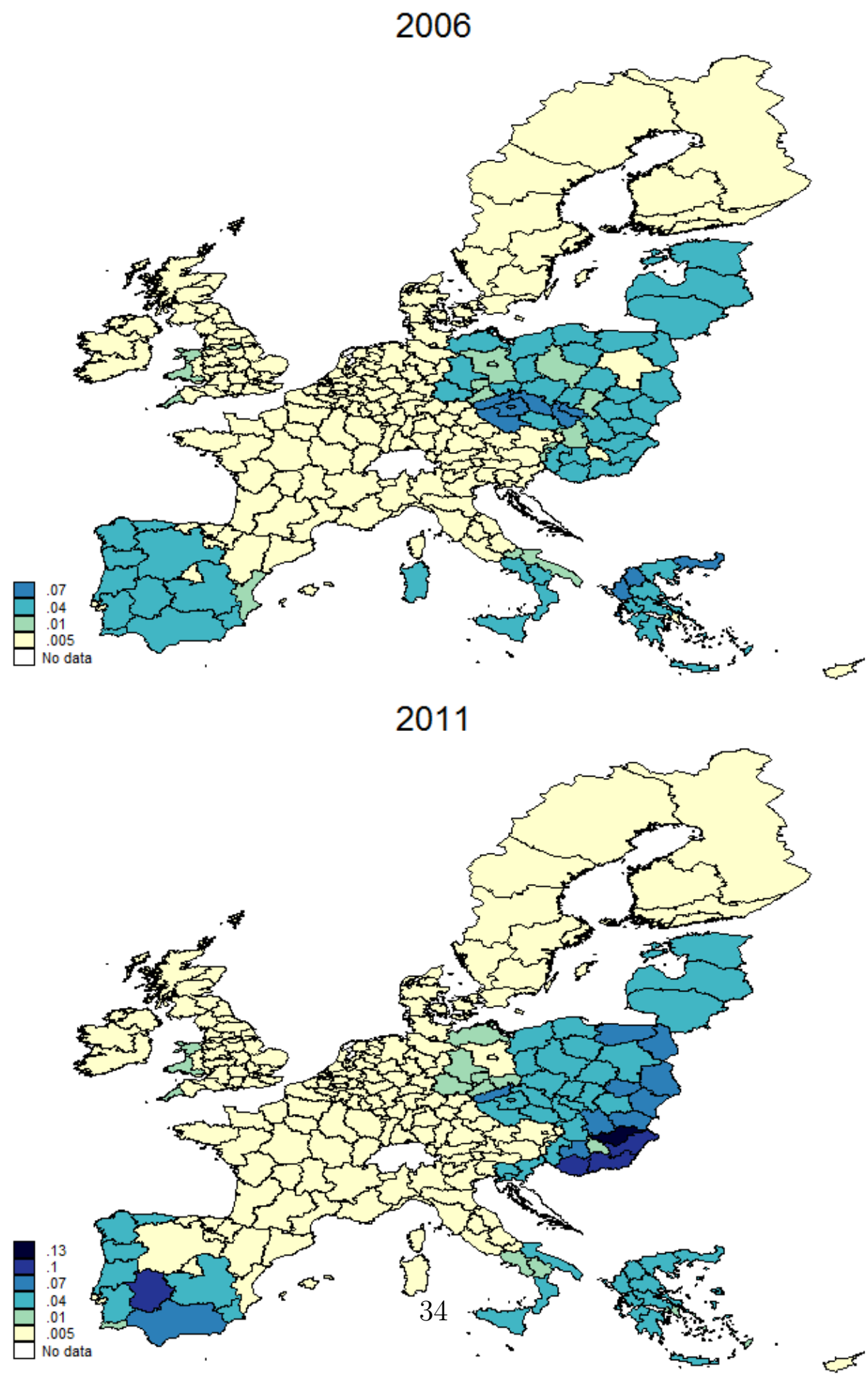

Figure 1: Annual commitments as a share of GDP by NUTS 2 (representative years, Objectives $1+2$ ) 


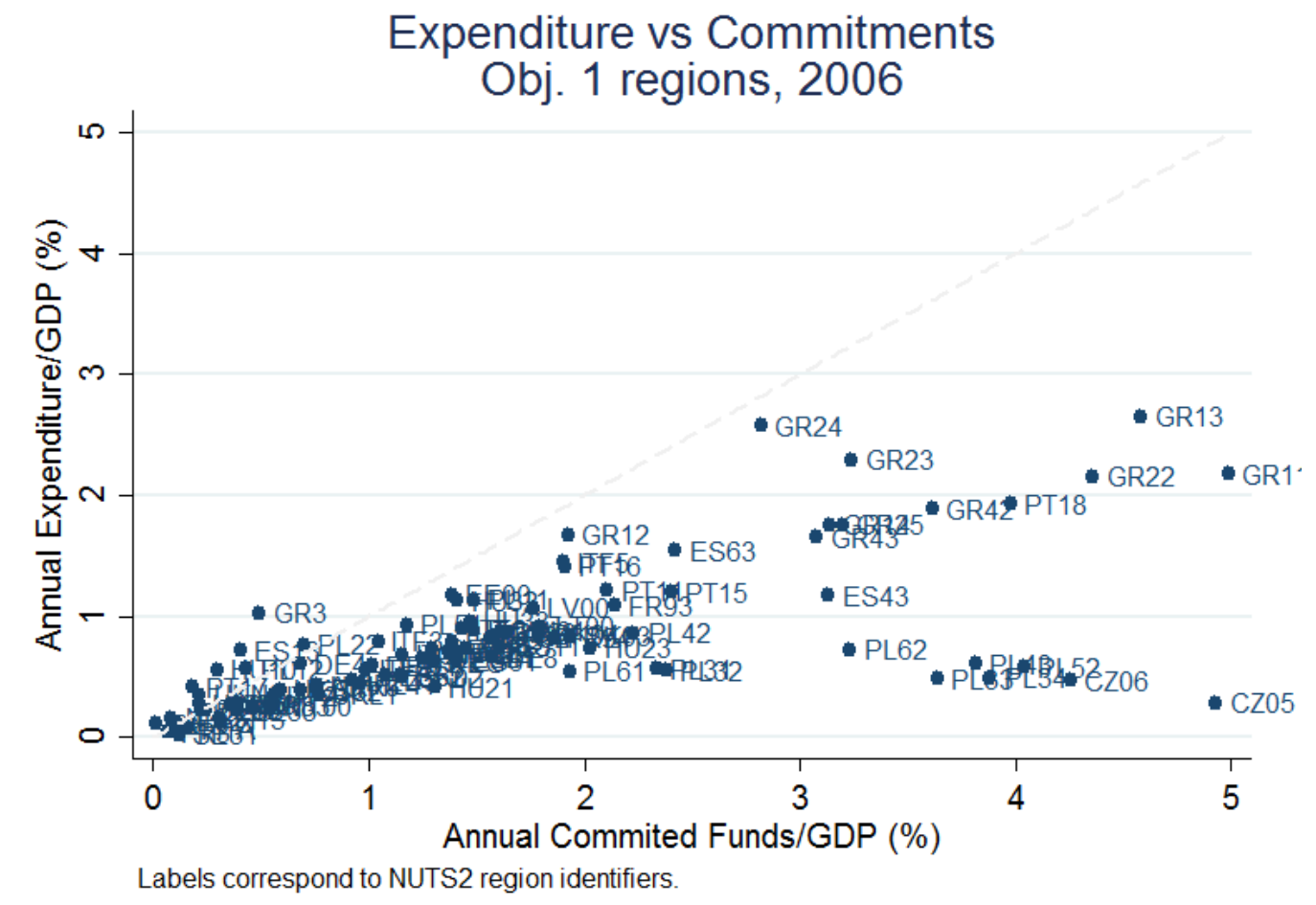

Figure 2: Key explanatory variable and instrumental variable for a representative year 


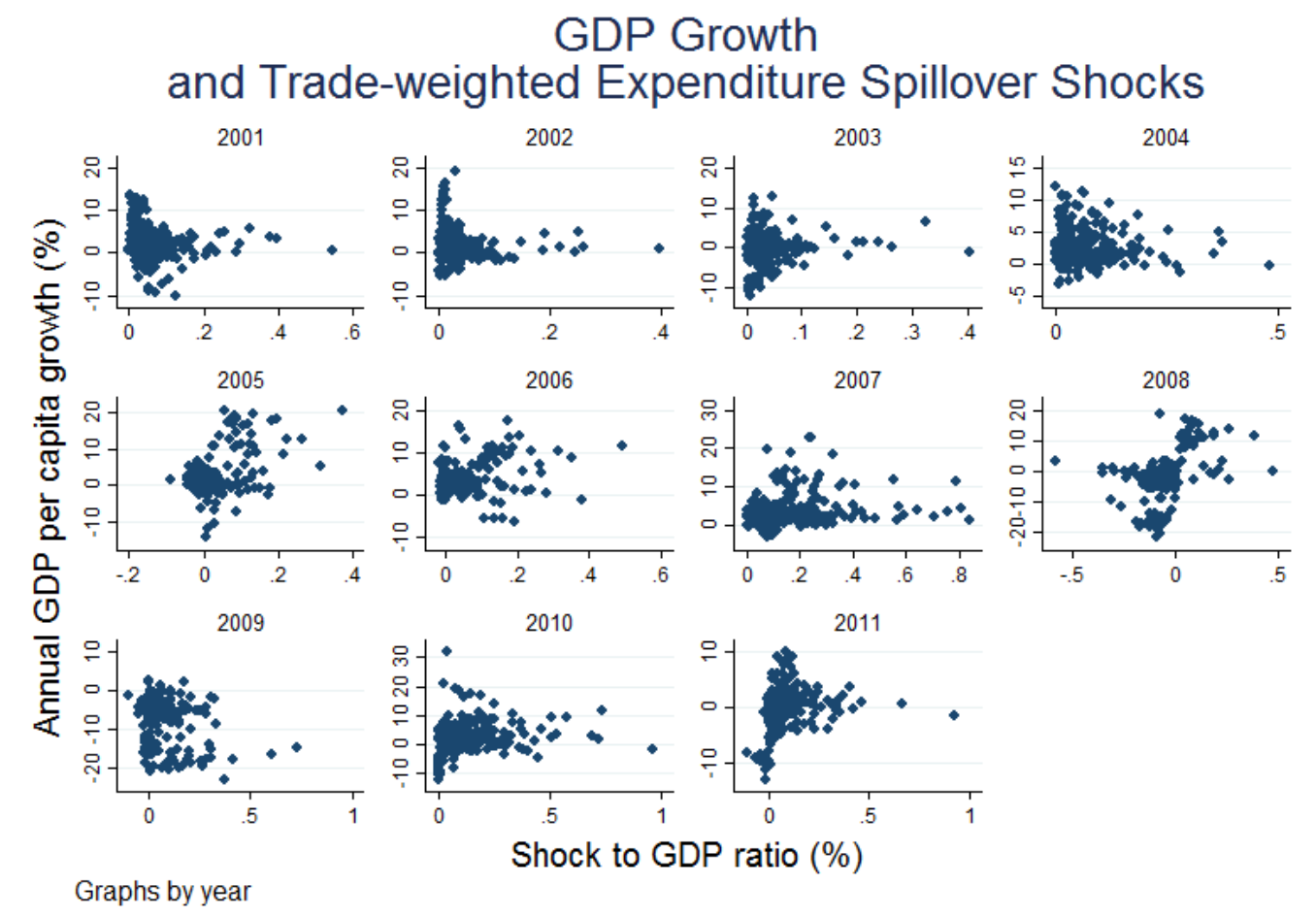

Figure 3: GDP Growth vs Trade-weighted Expenditure Spillover Shock: 2001-2011 


\section{Fuzzy regression discontinuity}

Several papers have exploited the discrete jump in probability of receiving Objective 1 transfers in a regression discontinuity design (Kallstrom (2014); Pellegrini et al. (2013)), though the most cited reference in this line of literature (and also the first one to really explore this design) remains Becker et al. (2010). As summarized earlier, the authors use a binary treatment variable (whether or not a NUTS 2 region was eligible for Objective 1 transfers) to estimate the local average treatment effect of structural funds on average GDP growth and employment within a programming period. The analysis below aims at mirroring the strategy used by Becker et al. (2010), but addressing a couple of its limitations which the data used in the panel instrumental variables exercise above enables me to do. In particular, instead of binary treatment, I use a continuous treatment variable (actual expenditures received), that is furthermore instrumented as in the panel IV above by corresponding commitments; the same rationale for instrumenting applies as before (endogeneity in expenditures with respect to aggregate demand conditions and measurement error). In addition, although the nature of the quasi-experimental design does arise from a discontinuity in eligibility for Objective 1 funds, I use the total amount of funds transferred to regions (including Objective 2 funds) as my treatment variable; the reason behind this choice is that using merely Objective 1 transfers implicitly attributes 0 valued transfers to most regions on the right-side of the discontinuity threshold, thus exacerbating the true treatment discontinuity ${ }^{19}$ and underestimating any existing treatment effect. As in robustness Table 10, I find some evidence of weaker treatment effects in the 2007-13 period, due likely to the particular choice of fiscal shock identification in levels - a necessary evil of the regression discontinuity criterion.

\footnotetext{
${ }^{19}$ Objective 2 regions also do receive some transfers. Although not as sizable as median Objective 1 transfers, the former are still "treated" observations, even while being a valid control group for Objective 1 regions. That continuity in treatment beyond the Objective 1 threshold is a feature often neglected by previous literature using the methodology in this section.
} 
Figure 4: Intended treatment given reference-period GDP per capita (forcing variable)

Figure 5: Realized treatment given reference-period GDP per capita (forcing variable)

Although I have data on annual commitments and expenditures by NUTS 2 region $^{20}$, the treatment assignment variable (running variable in the regression discontinuity created by the threshold of eligibility for Obj.1 funds, i.e. reference period GDP per capita) is unique per programming period. Thus, in what follows I estimate the local average treatment effect of Obj.1 fund eligibility separately for each programming period (the samples can of course also be pooled, treating each region as a separate region-programming period unit).

From the graphs below, it is apparent that we are dealing with a fuzzy discontinuity, since there are a few Obj.1 regions above the eligibility threshold. However, most regions receiving positive funds above that threshold are Obj.2 regions. Thus, a simple binary treatment regression discontinuity local average treatment effect estimation would vastly underestimate any actual effects, by imputing zero treatment on Obj.2 regions which actually get some federal funding (albeit significantly smaller than the Obj.1 sample on average). In addition, it is worthwhile noting that several Obj.1 regions are allocated funds at per capita levels comparable to Obj.2 regions in other words, Obj.1 treatment is highly heterogeneous, and comparisons should be made between those with high levels of transfers and regular Obj.2 regions, conditional on similar reference period GDP per capita, rather than all regions within a given band of the threshold.

For the "normal" 2000-06 programming period, we can see the graphical evidence in Figure 8 in support of a regression discontinuity design below: commitments

\footnotetext{
${ }^{20}$ There is also data on expenditures at the NUTS3 level for the 2000-06 period, but instruments exist at the NUTS 2 level only (by design). See Becker et al. (2012), who use this shorter period but more disaggregated dataset in a generalized propensity score setup.
} 


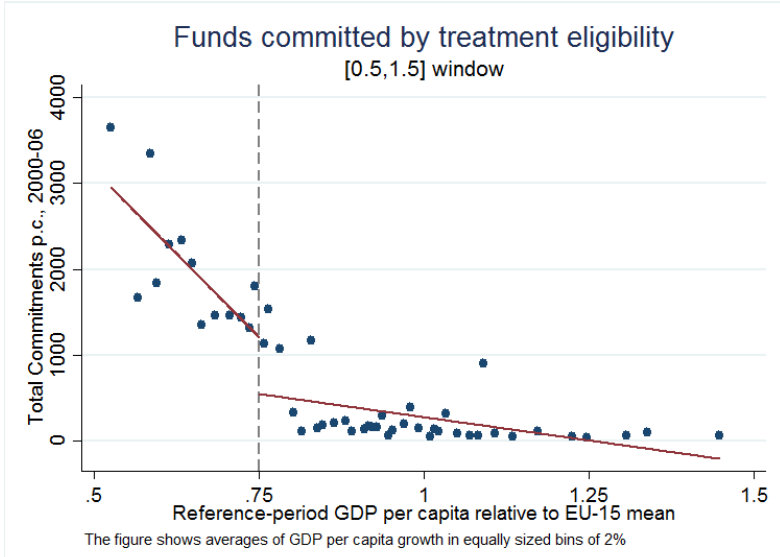

Figure 6: Funds committed (Euros per capita) by treatment eligibility: 2000-06 programming period

(per capita and as a share of initial GDP) show a discontinuity and change in slope (interaction effect) at the eligibility threshold with respect to the assignment variable (reference-period GDP per capita). However, when looking at the outcome variable (average real GDP growth), it is difficult to see such a discontinuity - if anything, my evidence goes in the opposite direction from that found by Becker et al. (2010), in that growth outcomes are slightly lower immediately before the threshold relative to those immediately after. This is apparent using linear fits or 5th order asymmetric polynomials on both sides of the threshold. Note in this graphical evidence we are using commitments, rather than expenditures as treatment, since the latter can be driven by local demand conditions (this was in fact the core motivation underlying our earlier broad sample IV estimation). Graphically, however, expenditures and commitments behave alike with respect to the assignment variable.

Since I have a continuous treatment variable with noncompliers to the treatment assignment rule (fuzzy design), the RD naturally has to be estimated in two stages. In addition to using a binary indicator of whether a region is above or below the threshold (the typical exclusive instrument for treatment in this setup), I add the respective commitments series as an additional instrument. In particular, the second 


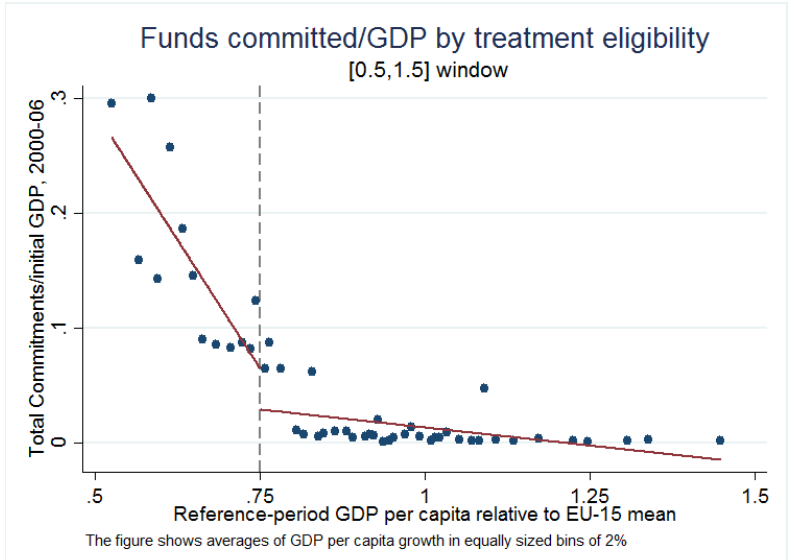

Figure 7: Funds committed (for entire programming period) as a share of initial annual GDP: 2000-06 programming period

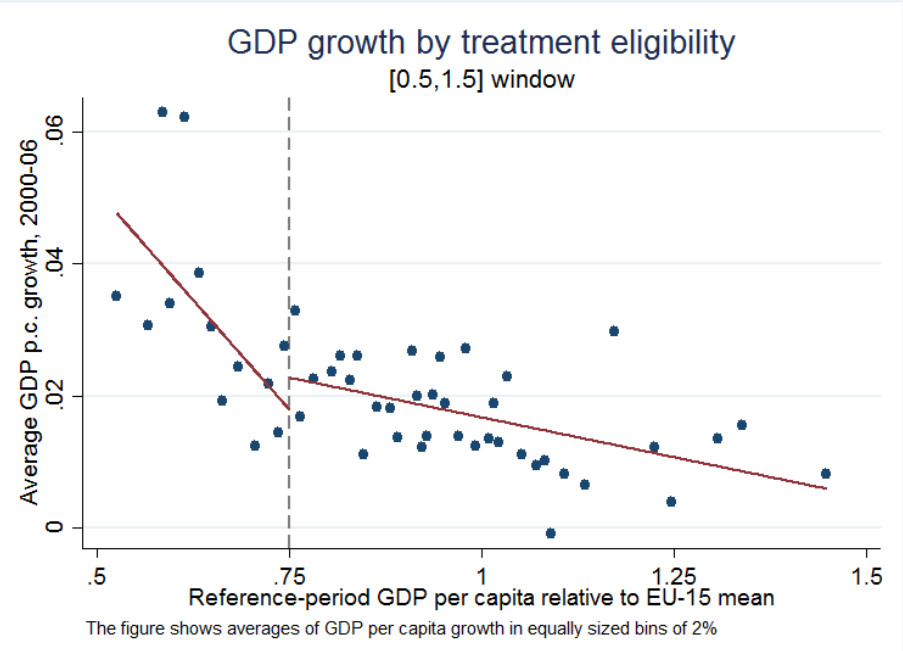

Figure 8: Average annual GDP per capita growth by treatment eligibility: 2000-06 programming period, EU-12 only 


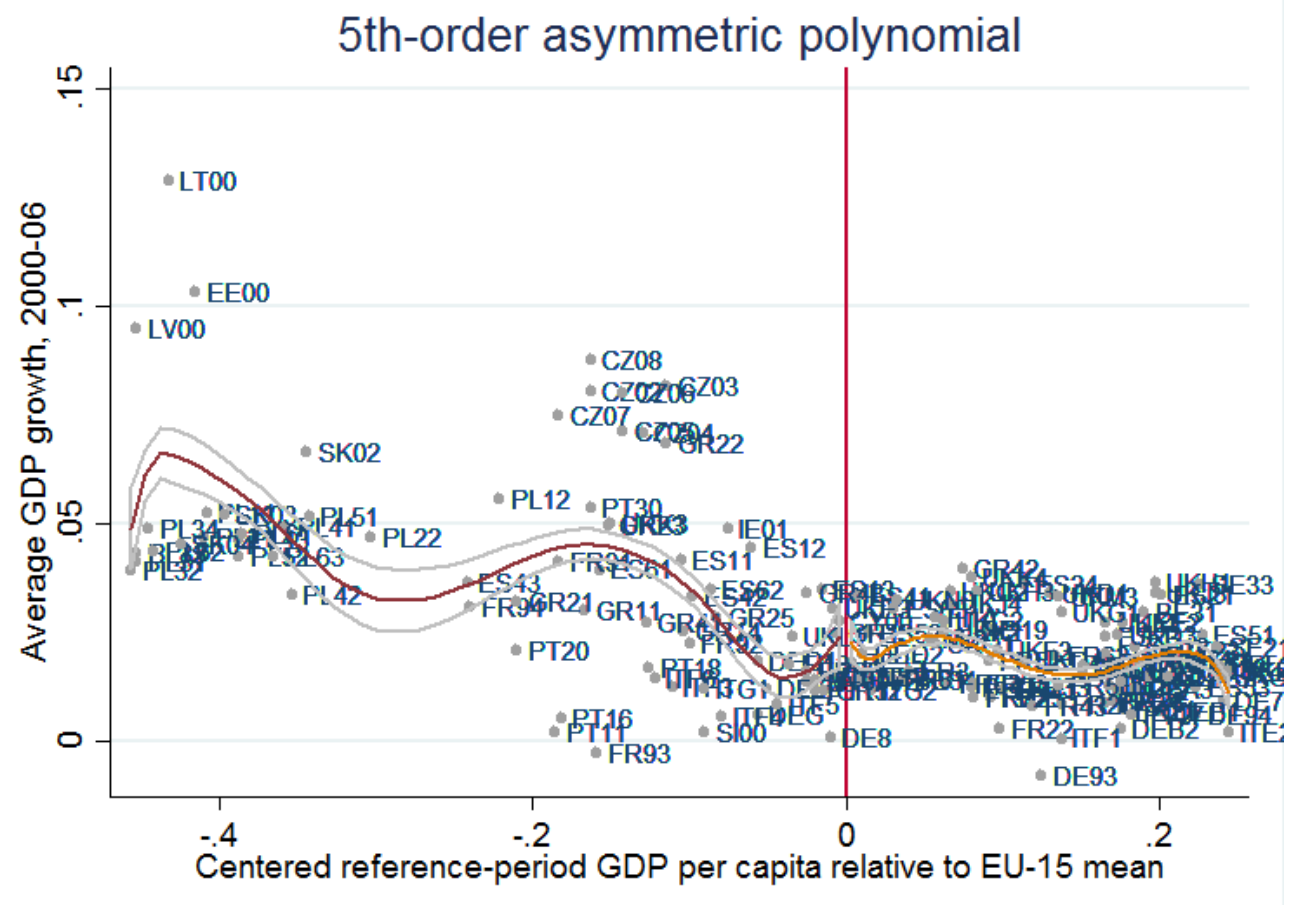

Figure 9: High-order polynomial approximation to the conditional expectation of average GDP per capita growth given the forcing variable 
stage specification is

$$
\frac{Y_{i, t}-Y_{i, t-1}}{Y_{i, t-1}}=\gamma_{t}+\alpha_{j}+\phi G_{i t}+g\left(F_{i t}\right)+\xi_{i t}
$$

where in the first stage I estimate

$$
G_{i t}=\theta_{t}+\nu_{j}+\delta \mathbb{1}\left[F_{i t}>0\right]+\beta C_{i t}+f\left(F_{i t}\right)+\epsilon_{i t}
$$

$g\left(F_{i t}\right)$ and $f\left(F_{i t}\right)$, functions of the forcing variable $F_{i t}$, are approximated by asymmetric polynomials on each side of the threshold, including interaction terms. In what follows, I treat the data as a pooled cross-section for each programming period, although year and country fixed effects are used, just as for the panel estimates above $^{21}$. I estimate the treatment assignment function in the first stage via $3 \mathrm{rd} / 5 \mathrm{th}$ degree asymmetric polynomial approximation of the total funds spent in a given programming period around the threshold ${ }^{22}$. The outcome variable then on the second stage is the annual GDP per capita growth rate over the respective years.

While I find a large LATE consistent with the IV results above for the 2000-06 period (consistent with the findings of Becker et al. (2010)), the same is not true of the 2007-13 period. Looking at the yearly cross-section of GDP vs forcing (or assignment) variable, we see that the 2000-06 negative correlation pattern persists through 2007, starts shifting towards no correlation during 2008-09 as most regions in the Eurozone head towards negative growth territory, and is inverted in 2010 and 2011, as regions in Greece, Portugal and Spain remain at negative growth rates (trapped at the epicenter of the then emerging sovereign debt crisis), while other countries start to recover from the 2008 recession. In other words, there were asymmetric macroeconomic shocks at the country level affecting these regions over time which blur the normally observed

\footnotetext{
${ }^{21}$ The results are robust to their exclusion.

${ }^{22}$ Restricting the analysis as in Imbens and Lemieux (2008) to a narrow band around the threshold (rather than using the entire sample) would eliminate the results presented here, partially due to smaller sample size, but also due to the similarity in outcomes around the threshold evidenced in the graphs above.
} 
Table 13: Regression Discontinuity IV (NUTS 2 level), 2000-2011

Annual, 2000-06 Annual, 2007-13

\begin{tabular}{lccc} 
& 3rd order & 5th order & 3rd order \\
\hline Annual Expenditure per GDP, 2000-06 & $2.655^{* *}$ & $2.750^{* *}$ & \\
& $(1.117)$ & $(1.139)$ & \\
Annual Expenditure per GDP, 2007-13 & & & $0.350^{*}$ \\
& & & $(0.190)$ \\
\hline $\mathrm{N}$ & 1610 & 1610 & 1220 \\
\hline \hline
\end{tabular}

Standard errors in parentheses

Annual specifications include year and country fixed effects.

Clustered s.e.s at NUTS 2 level.

$*_{p}<0.1, * *<0.05, * * *<0.01$

positive correlation between the forcing variable and GDP growth ${ }^{23}$. Furthermore, some of the reasons related to the particular interference of the recent financial and sovereign debt crisis with the allocation mechanisms of these transfers may also contribute to explain the unusual results. This contrasts with the stronger-inrecession measured multipliers in the panel IV estimation core section of this paper using year-on-year changes in expenditures as the fiscal shock of interest, in line with the cross-country findings of Auerbach and Gorodnichenko (2012).

It is worthwhile noting that, in contrast to the earlier panel IV, the coefficient estimates on Table 13 cannot be directly interpreted as fiscal multipliers. Rather, they reflect an average response over the medium-run (the length of a programming period, 6-7 years) to ongoing treatment levels. Recall the independent variable of interest in the $\mathrm{RD}$ is the level of transfers (as a ratio to population or GDP), rather than a change in levels, or a shock per se whose propagation can be estimated in subsequent years.

\footnotetext{
${ }^{23}$ Becker, Egger and von Ehrlich find that correlation for the 1989-1993, 1994-1999 and 2000-06 programming periods, although looking at the fine print, the 1994-99 effect on average GDP growth they measure using RDD is only significant at the $15 \%$ level, and in all cases the coefficient is around $1 \%$ (so that treated regions grow on average $1 \%$ a year more than non-treated ones).
} 


\section{Index of Working Papers:}

\begin{tabular}{|c|c|c|c|}
\hline $\begin{array}{l}\text { March 29, } \\
2010\end{array}$ & Markus Knell & 161 & $\begin{array}{l}\text { Nominal and Real Wage Rigidities. } \\
\text { In Theory and in Europe }\end{array}$ \\
\hline May 31, 2010 & $\begin{array}{l}\text { Zeno Enders } \\
\text { Philip Jung } \\
\text { Gernot J. Müller }\end{array}$ & 162 & Has the Euro changed the Business Cycle? \\
\hline $\begin{array}{l}\text { August 25, } \\
2010\end{array}$ & $\begin{array}{l}\text { Marianna Cervená } \\
\text { Martin Schneider }\end{array}$ & 163 & $\begin{array}{l}\text { Short-term forecasting GDP with a DSGE } \\
\text { model augmented by monthly indicators }\end{array}$ \\
\hline $\begin{array}{l}\text { September 8, } \\
2010\end{array}$ & $\begin{array}{l}\text { Sylvia Kaufmann } \\
\text { Johann Scharler }\end{array}$ & 164 & $\begin{array}{l}\text { Bank-Lending Standards, the Cost Channel } \\
\text { and Inflation Dynamics }\end{array}$ \\
\hline $\begin{array}{l}\text { September 15, } \\
2010\end{array}$ & Helmut Elsinger & 165 & $\begin{array}{l}\text { Independence Tests based on Symbolic } \\
\text { Dynamics }\end{array}$ \\
\hline $\begin{array}{l}\text { December 14, } \\
2010\end{array}$ & Claudia Kwapil & 166 & $\begin{array}{l}\text { Firms' Reactions to the Crisis and their } \\
\text { Consequences for the Labour Market. } \\
\text { Results of a Company Survey conducted in } \\
\text { Austria }\end{array}$ \\
\hline May 10, 2011 & Helmut Stix & 167 & $\begin{array}{l}\text { Does the Broad Public Want to Consolidate } \\
\text { Public Debt? - The Role of Fairness and of } \\
\text { Policy Credibility }\end{array}$ \\
\hline May 11, 2011 & $\begin{array}{l}\text { Burkhard Raunig, } \\
\text { Johann Scharler }\end{array}$ & 168 & $\begin{array}{l}\text { Stock Market Volatility, Consumption and } \\
\text { Investment; An Evaluation of the Uncertainty } \\
\text { Hypothesis Using Post-War U.S. Data }\end{array}$ \\
\hline May 23, 2011 & Steffen Osterloh & 169 & $\begin{array}{l}\text { Can Regional Transfers Buy Public } \\
\text { Support? Evidence from EU Structural } \\
\text { Policy }\end{array}$ \\
\hline May 23, 2011 & $\begin{array}{l}\text { Friederike Niepmann } \\
\text { Tim Schmidt-Eisenlohr }\end{array}$ & 170 & $\begin{array}{l}\text { Bank Bailouts, International Linkages and } \\
\text { Cooperation }\end{array}$ \\
\hline $\begin{array}{l}\text { September 1, } \\
2011\end{array}$ & $\begin{array}{l}\text { Jarko Fidrmuc, } \\
\text { Mariya Hake, } \\
\text { Helmut Stix }\end{array}$ & 171 & $\begin{array}{l}\text { Households' Foreign Currency Borrowing in } \\
\text { Central and Eastern Europe }\end{array}$ \\
\hline $\begin{array}{l}\text { September 9, } \\
2011\end{array}$ & $\begin{array}{l}\text { Jürgen Eichberger, } \\
\text { Klaus Rheinberger, } \\
\text { Martin Summer }\end{array}$ & 172 & Credit Risk in General Equilibrium \\
\hline
\end{tabular}




\begin{tabular}{|c|c|c|c|}
\hline $\begin{array}{l}\text { October 6, } \\
2011\end{array}$ & Peter Lindner & 173 & $\begin{array}{l}\text { Decomposition of Wealth and Income using } \\
\text { Micro Data from Austria }\end{array}$ \\
\hline $\begin{array}{l}\text { October 18, } \\
2011\end{array}$ & Stefan Kerbl & 174 & $\begin{array}{l}\text { Regulatory Medicine Against Financial } \\
\text { Market Instability: } \\
\text { What Helps And What Hurts? }\end{array}$ \\
\hline $\begin{array}{l}\text { December 31, } \\
2011\end{array}$ & $\begin{array}{l}\text { Konstantins Benkovskis } \\
\text { Julia Wörz }\end{array}$ & 175 & How Does Quality Impact on Import Prices? \\
\hline $\begin{array}{l}\text { January 17, } \\
2012\end{array}$ & Nicolás Albacete & 176 & $\begin{array}{l}\text { Multiple Imputation in the Austrian } \\
\text { Household Survey on Housing Wealth }\end{array}$ \\
\hline $\begin{array}{l}\text { January 27, } \\
2012\end{array}$ & $\begin{array}{l}\text { Gerhard Fenz, } \\
\text { Lukas Reiss, } \\
\text { Martin Schneider }\end{array}$ & 177 & $\begin{array}{l}\text { A structural interpretation of the impact of } \\
\text { the great recession on the Austrian } \\
\text { economy using an estimated DSGE model }\end{array}$ \\
\hline $\begin{array}{l}\text { July } 27 \\
2012\end{array}$ & Helmut Stix & 178 & $\begin{array}{l}\text { Why Do People Save in Cash? Distrust, } \\
\text { Memories of Banking Crises, Weak } \\
\text { Institutions and Dollarization }\end{array}$ \\
\hline $\begin{array}{l}\text { August 20, } \\
2012\end{array}$ & Markus Knell & 179 & $\begin{array}{l}\text { Increasing Life Expectancy and Pay-As- } \\
\text { You-Go Pension Systems }\end{array}$ \\
\hline $\begin{array}{l}\text { September 25, } \\
2012\end{array}$ & $\begin{array}{l}\text { Fabio Rumler, } \\
\text { Walter Waschiczek }\end{array}$ & 180 & $\begin{array}{l}\text { Have Changes in the Financial Structure } \\
\text { Affected Bank Protability? Evidence for } \\
\text { Austria }\end{array}$ \\
\hline $\begin{array}{l}\text { November 9, } \\
2012\end{array}$ & $\begin{array}{l}\text { Elisabeth Beckmann, } \\
\text { Jarko Fidrmuc, } \\
\text { Helmut Stix }\end{array}$ & 181 & $\begin{array}{l}\text { Foreign Currency Loans and Loan Arrears } \\
\text { of Households in Central and Eastern } \\
\text { Europe }\end{array}$ \\
\hline $\begin{array}{l}\text { June 10, } \\
2013\end{array}$ & Luca Fornaro & 182 & International Debt Deleveraging \\
\hline $\begin{array}{l}\text { June 10, } \\
2013\end{array}$ & $\begin{array}{l}\text { Jenny Simon, } \\
\text { Justin Valasek }\end{array}$ & 183 & $\begin{array}{l}\text { Efficient Fiscal Spending by Supranational } \\
\text { Unions }\end{array}$ \\
\hline $\begin{array}{l}\text { July 24, } \\
2013\end{array}$ & $\begin{array}{l}\text { Thomas Breuer, Hans- } \\
\text { Joachim Vollbrecht, } \\
\text { Martin Summer }\end{array}$ & 184 & $\begin{array}{l}\text { Endogenous Leverage and Asset Pricing in } \\
\text { Double Auctions }\end{array}$ \\
\hline $\begin{array}{l}\text { September 23, } \\
2013\end{array}$ & Martin Feldkircher & 185 & A Global Macro Model for Emerging Europe \\
\hline $\begin{array}{l}\text { September 25, } \\
2013\end{array}$ & $\begin{array}{l}\text { Martin Gächter, } \\
\text { Aleksandra Riedl }\end{array}$ & 186 & $\begin{array}{l}\text { One Money, One Cycle? The EMU } \\
\text { Experience }\end{array}$ \\
\hline
\end{tabular}




\begin{tabular}{|c|c|c|c|}
\hline $\begin{array}{l}\text { December 9, } \\
2013\end{array}$ & $\begin{array}{l}\text { Stefan Niemann, } \\
\text { Paul Pichler }\end{array}$ & 187 & Collateral, Liquidity and Debt Sustainability \\
\hline $\begin{array}{l}\text { March 6, } \\
2014\end{array}$ & $\begin{array}{l}\text { Elisabeth Beckmann, } \\
\text { Helmut Stix }\end{array}$ & 188 & $\begin{array}{l}\text { Foreign currency borrowing and knowledge } \\
\text { about exchange rate risk }\end{array}$ \\
\hline $\begin{array}{l}\text { March 10, } \\
2014\end{array}$ & $\begin{array}{l}\text { Jesús Crespo } \\
\text { Cuaresma, } \\
\text { Martin Feldkircher, } \\
\text { Florian Huber }\end{array}$ & 189 & $\begin{array}{l}\text { Forecasting with Bayesian Global Vector } \\
\text { Autoregressive Models: } \\
\text { A Comparison of Priors }\end{array}$ \\
\hline $\begin{array}{l}\text { May 12, } \\
2014\end{array}$ & Claudia Steinwender & 190 & $\begin{array}{l}\text { Information Frictions and the Law of One } \\
\text { Price: "When the States and the Kingdom } \\
\text { became United" }\end{array}$ \\
\hline $\begin{array}{l}\text { May 12, } \\
2014\end{array}$ & Saleem A. Bahaj & 191 & $\begin{array}{l}\text { Systemic Sovereign Risk: Macroeconomic } \\
\text { Implications in the Euro Area }\end{array}$ \\
\hline $\begin{array}{l}\text { May 16, } \\
2014\end{array}$ & $\begin{array}{l}\text { John Bagnall, } \\
\text { David Bounie, } \\
\text { Kim P. Huynh, } \\
\text { Anneke Kosse, } \\
\text { Tobias Schmidt, } \\
\text { Scott Schuh and } \\
\text { Helmut Stix }\end{array}$ & 192 & $\begin{array}{l}\text { Consumer Cash Usage: A Cross-Country } \\
\text { Comparison with Payment Diary Survey } \\
\text { Data }\end{array}$ \\
\hline $\begin{array}{l}\text { May 19, } \\
2014\end{array}$ & $\begin{array}{l}\text { Konstantins Benkovskis } \\
\text { Julia Wörz }\end{array}$ & 193 & $\begin{array}{l}\text { "Made in China" - How Does it Affect } \\
\text { Measures of Competitiveness? }\end{array}$ \\
\hline $\begin{array}{l}\text { June 25, } \\
2014\end{array}$ & $\begin{array}{l}\text { Burkhard Raunig, } \\
\text { Johann Scharler and } \\
\text { Friedrich Sindermann }\end{array}$ & 194 & Do Banks Lend Less in Uncertain Times? \\
\hline $\begin{array}{l}\text { July 28, } \\
2014\end{array}$ & $\begin{array}{l}\text { Martin Feldkircher and } \\
\text { Florian Huber }\end{array}$ & 195 & $\begin{array}{l}\text { The International Transmission of U.S. } \\
\text { Structural Shocks - Evidence from Global } \\
\text { Vector Autoregressions }\end{array}$ \\
\hline $\begin{array}{l}\text { September 16, } \\
2014\end{array}$ & $\begin{array}{l}\text { Kim P. Huynh, } \\
\text { Philipp Schmidt- } \\
\text { Dengler, } \\
\text { Helmut Stix }\end{array}$ & 196 & $\begin{array}{l}\text { The Role of Card Acceptance in the } \\
\text { Transaction; Demand for Money }\end{array}$ \\
\hline $\begin{array}{l}\text { October 10, } \\
2014\end{array}$ & $\begin{array}{l}\text { Martin Brown, } \\
\text { Helmut Stix }\end{array}$ & 197 & $\begin{array}{l}\text { The Euroization of Bank Deposits in Eastern } \\
\text { Europe }\end{array}$ \\
\hline $\begin{array}{l}\text { October 17, } \\
2014\end{array}$ & $\begin{array}{l}\text { Ludmila Fadejeva, } \\
\text { Martin Feldkircher, } \\
\text { Thomas Reininger }\end{array}$ & 198 & $\begin{array}{l}\text { Spillovers from Euro Area and U.S. Credit } \\
\text { and Demand Shocks: Comparing Emerging } \\
\text { Europe on the Basis of a GVAR Model }\end{array}$ \\
\hline
\end{tabular}




\begin{tabular}{|c|c|c|c|}
\hline $\begin{array}{l}\text { December 18, } \\
2014\end{array}$ & Esther Segalla & 199 & $\begin{array}{l}\text { Shock Transmission through International } \\
\text { Banks: Austria }\end{array}$ \\
\hline $\begin{array}{l}\text { March 5, } \\
2015\end{array}$ & $\begin{array}{l}\text { Jonas Dovern, } \\
\text { Martin Feldkircher, } \\
\text { Florian Huber }\end{array}$ & 200 & $\begin{array}{l}\text { Does Joint Modelling of the World Economy } \\
\text { Pay Off? Evaluating Global Forecasts from a } \\
\text { Bayesian GVAR }\end{array}$ \\
\hline $\begin{array}{l}\text { May 19, } \\
2015\end{array}$ & Markus Knell & 201 & $\begin{array}{l}\text { The Return on Social Security with } \\
\text { Increasing Longevity }\end{array}$ \\
\hline $\begin{array}{l}\text { June 15, } \\
2015\end{array}$ & Anil Ari & 202 & Sovereign Risk and Bank Risk-Taking \\
\hline $\begin{array}{l}\text { June 15, } \\
2015\end{array}$ & Matteo Crosignani & 203 & $\begin{array}{l}\text { Why Are Banks Not Recapitalized During } \\
\text { Crises? }\end{array}$ \\
\hline $\begin{array}{l}\text { February 19, } \\
2016\end{array}$ & Burkhard Raunig & 204 & Background Indicators \\
\hline $\begin{array}{l}\text { February 22, } \\
2016\end{array}$ & $\begin{array}{l}\text { Jesús Crespo } \\
\text { Cuaresma, } \\
\text { Gernot Doppelhofer, } \\
\text { Martin Feldkircher, } \\
\text { Florian Huber }\end{array}$ & 205 & US Monetary Policy in a Globalized World \\
\hline $\begin{array}{l}\text { March 4, } \\
2016\end{array}$ & $\begin{array}{l}\text { Helmut Elsinger, } \\
\text { Philipp Schmidt- } \\
\text { Dengler, } \\
\text { Christine Zulehner }\end{array}$ & 206 & Competition in Treasury Auctions \\
\hline $\begin{array}{l}\text { May 14, } \\
2016\end{array}$ & $\begin{array}{l}\text { Apostolos } \\
\text { Thomadakis }\end{array}$ & 207 & $\begin{array}{l}\text { Determinants of Credit Constrained Firms: } \\
\text { Evidence from Central and Eastern Europe } \\
\text { Region }\end{array}$ \\
\hline $\begin{array}{l}\text { July } 1 \\
2016\end{array}$ & $\begin{array}{l}\text { Martin Feldkircher, } \\
\text { Florian Huber }\end{array}$ & 208 & $\begin{array}{l}\text { Unconventional US Monetary Policy: New } \\
\text { Tools Same Channels? }\end{array}$ \\
\hline $\begin{array}{l}\text { November 24, } \\
2016\end{array}$ & François de Soyres & 209 & $\begin{array}{l}\text { Value Added and Productivity Linkages } \\
\text { Across Countries }\end{array}$ \\
\hline $\begin{array}{l}\text { November 25, } \\
2016\end{array}$ & Maria Coelho & 210 & $\begin{array}{l}\text { Fiscal Stimulus in a Monetary Union: } \\
\text { Evidence from Eurozone Regions }\end{array}$ \\
\hline
\end{tabular}




\section{Call for Entries: \\ Visiting Research Program}

The Oesterreichische Nationalbank (OeNB) invites applications from external researchers for participation in a Visiting Research Program established by the OeNB's Economic Analysis and Research Department. The purpose of this program is to enhance cooperation with members of academic and research institutions (preferably post-doc) who work in the fields of macroeconomics, international economics or financial economics and/or with a regional focus on Central, Eastern and Southeastern Europe.

The OeNB offers a stimulating and professional research environment in close proximity to the policymaking process. Visiting researchers are expected to collaborate with the OeNB's research staff on a prespecified topic and to participate actively in the department's internal seminars and other research activities. They will be provided with accommodation on demand and habe, as a rule, access to the department's data and computer resources and to research assistance. Their research output may be published in one of the department's publication outlets or as an OeNB Working Paper. Research visits should ideally last between 3 and 6 months, but timing is flexible.

Applications (in English) should include

- a curriculum vitae,

- a research proposal that motivates and clearly describes the envisaged research project,

- an indication of the period envisaged for the research visit, and

- information on previous scientific work.

Applications for 2017 should be e-mailed to eva.gehringer-wasserbauer@oenb.at by May 1, 2017.

Applicants will be notified of the jury's decision by mid-June. The following round of applications will close on November 1, 2017. 